\title{
Social Hierarchies and the Formation of Customary Property Law in Pre-Industrial China and England
}

Taisu Zhang*

Spring 2013

\begin{abstract}
Comparative lawyers and economists have often assumed that traditional Chinese laws and customs reinforced the economic and political dominance of elites and, therefore, were unusually "despotic" towards the poor. Such assumptions are highly questionable: Quite the opposite, one of the most striking characteristics of Qing and Republican property institutions is that they often gave significantly greater economic protection to the poorer segments of society than comparable institutions in early modern England. In particular, Chinese property customs afforded much stronger powers of redemption to landowners who had pawned their land. In both societies, land-pawning occurred far more frequently among poorer households than richer ones, but Chinese customary law allowed debtors to indefinitely retain redemption rights over collateralized property, whereas English debtors would generally lose the property permanently if they failed to redeem within one year.

This article argues that the comparatively "egalitarian" tendencies of Qing and Republican property institutions stemmed from the different ways Chinese and English rural communities allocated social status and rank. Hierarchical "Confucian" kinship networks dominated social and economic life in most Chinese villages. Within these networks, an individual's status and rank depended, in large part, on his age and generational seniority, rather than personal wealth. This allowed many low-income households to enjoy status and rank quite disproportionate to their wealth. In comparison, substantial landed wealth was generally a prerequisite for high status in early modern England, effectively excluding lower-income households from positions of sociopolitical authority. Chinese smallholders possessed, therefore, significantly more social bargaining power, and were more capable of negotiating desirable property institutions. Paradoxically, the predominance of kinship hierarchies actually enhanced macro-level political and economic equality.
\end{abstract}

Category: Comparative Legal History

Keywords: Kinship, Hierarchy, Social Status, Social Norms, Custom, Mortgages, "Dian,” Confucianism

\footnotetext{
* Visiting Assistant Professor, Duke University School of Law; Ph.D. Candidate, Yale University History Department; J.D., Yale Law School. This project was made possible by a Prize Fellowship from the Yale East Asian Council. I also thank the American Society for Legal History for recognizing an earlier draft with a Kathryn T. Preyer Award. For comments and suggestions, I thank Peter Perdue, James Whitman, Robert Ellickson, Steven Pincus, Ralf Michaels, Jedediah Purdy, Paul Haagen, William Alford, Kenneth Pomeranz, Madeleine Zelin, Jonathan Ocko, Mathias Reimann, Nicholas Howson, Chiu Pengsheng, Wang Zhiqiang, James Oldham, Harold Tanner, and participants of presentations at Duke University, Columbia University, the University of Indiana, Bloomington, the American Society of Legal History, and the American Historical Association.
} 


\section{Introduction}

One of the oldest and most influential assumptions about traditional Chinese law and custom is that they endorsed unusually severe socioeconomic inequality. As one prominent comparative lawyer surmised quite recently, Chinese law and custom displayed, even in the early $20^{\text {th }}$ Century, "a strongly hierarchical view of society; a high value placed on harmony; ... [and a] hierarchical structure of the society counterbalancing egalitarian organization." "These institutional hierarchies purportedly reinforced both the political and economic dominance of elites, but subjected most of the population to oppression and economic disparity ${ }^{2}$ - and therefore belonged in the same legal family as the Indian caste system or Japanese feudalism. ${ }^{3}$ Such assumptions remain resiliently influential in current debates over, for example, why the Chinese economy comparatively "underdeveloped" after the Eighteenth Century, ${ }^{4}$ and why Mainland China lacks the "rule of law." The echoes of Max Weber and Karl Wittfogel, categorizing the Chinese legal tradition as "irrational," or simply as "oriental despotism," are inescapable. ${ }^{6}$

At the same time, however, historians have increasingly realized that traditional Chinese property institutions afforded unusually high levels of economic protection to poorer rural households. ${ }^{7}$ Their egalitarian tendencies are especially poignant when

\footnotetext{
${ }^{1}$ Ugo Mattei, Three Patterns of Law: Taxonomy and Change in the World's Legal Systems, 45 AM. J. ComP. L. 5, 39 (1997). For similar sentiments, see, e.g., ZHANG JINFAN, ZHONGGUO FALÜ DE CHUANTONG YU JiNDAi ZHUANXING [THE TRADITIONS AND EARLY MODERN TRANSFORMATION OF CHINESE LAW] 72 (1997); GEOFFrey MACCORMACK, THE SPIRIT OF TRADITIONAL CHINESE LAW 52-144 (1996); ROBERTO UnGER, LAW IN MODERN SOCIETY: TOWARDS A CRITICISM OF SOCIAL THEORY 93 (1976); DERK BODDE \& ClARENCE MorRis, LAW IN IMPERIAL CHINA 29-38 (1967); Amir N. Licht, et al., Culture rules: The foundations of the rule of law and other norms of governance, 35 J. COMP. ECON. 659, 660, 684 (2007); John O. Haley, Law and Culture in China and Japan: A Framework for Analysis, 27 MICH. J. INT'L L. 895, 906 (2006); Enforcing Civility and Respect: Three Societies, 109 YALE L.J. 1279, 1320 (2000); Albert H.Y. Chen, Towards a Legal Enlightenment: Discussions in Contemporary China on the Rule of Law, 17 UCLA PAC. BASIN L.J. 125, 130 (2000) (summarizing the academic consensus in mainland China that traditional Chinese legal culture was "hierarchical and oppressive"); Teemu Ruskola, Law, Sexual Morality, and Gender Equality in Qing and Communist China, 103 YALE L.J. 2531, 2531-37 (1994).

${ }^{2}$ E.g., G.W.F. Hegel, THE PHILOSOPHY OF History 112 (J. Sibree trans., 1956); THOMAS B. STEPHENS, ORDER AND DisCIPLINE IN CHINA: THE SHANGHAi MiXed COURT, 1911-27, at 115 (1992); KARL A. WitTFOGEL, ORIENTAL DESPOTISM: A COMPARATIVE STUDY OF TOTAL POWER (1957); Chen, supra note 1; ZHANG, supra note 1 .

${ }^{3}$ Mattei, supra note 1.

${ }^{4}$ Some of the best-known examples include DARON ACEMOGLU \& JAMES A. RoBinson, Why NATIONS FAIL: THE ORIGINS OF POWER, PROSPERITY AND POVERTY 117 (2010) (attributing Chinese underdevelopment to the unchecked power of its ruling elite); JÜRGEN HABERMAS, THE POSTNATIONAL Constellation: Political Essays 124 (M. Pensky, Trans., 2001) (arguing that Asian societies must discard their hierarchical legal institutions to achieve capitalist modernity); ERIC L. JONES, GROWTH RECURRING: ECONOMIC CHANGE IN WORLD HISTORY 130-46 (1988); and WITTFOGEL, supra note 2. ${ }^{5}$ E.g., Licht et al., supra note 1; Haley, supra note 1, at 915.

${ }^{6}$ See MAX WeBER, ECONOMY AND SOCIETY 1063 (Guenther Roth and Claus Wittich eds., 1968); MAX WEBER ON LAW IN ECONOMY AND SOCIETY 232-44 (Max Rheinstein ed., 1954). For criticism, see Robert M. Marsh, Weber's Misunderstanding of Chinese Law, 106 AM. J. SociOL. 281 (2000). On oriental despotism, see WITTFOGEL, supra note 1.

${ }^{7}$ E.g., Robert Brenner \& Christopher Isett, England's Divergence from China's Yangtze Delta: Property Relations, Microeconomics, and Patterns of Development, 61 J. ASIAN STUD. 609 (2002); Robert C.
} 
compared with early modern Western, particularly English, property institutions. One especially compelling example is the redemption of collateralized property, a vital concern for lower-income households that relied on land-pawning instruments - "dian" sales ("conditional sales") in Qing and Republican China ${ }^{8}$ and mortgages in early modern England - for monetary liquidity. ${ }^{9}$ Despite vigorous opposition by the wealthiest segments of society, customary law in most of China granted "dian" sellers - in other words, "land pawnors" - an essentially unlimited right of redemption, viable for decades after the initial sale. ${ }^{10}$ In comparison, early modern English institutions generally allowed creditors to permanently seize mortgaged land if the debtor failed to repay within a year, thereby encouraging the aggressive consolidation of land into large private estates. $^{11}$

Can these two themes, one of prevalent sociolegal hierarchy and one of strongly egalitarian property institutions, coexist in our understanding of the Chinese legal tradition? One possible solution is to portray both as symptoms of a backward, "premodern" society. Several historians have, indeed, attributed the peculiarly strong protection of land redemption rights in Chinese property customs to certain cultural, even semi-religious, characteristics that directly encouraged such protection: Chinese rural communities adhered, they claim, to "precommerical" moral ideals of "permanence in landholding," partially due to the lack of market integration, labor mobility, and economic specialization. ${ }^{12}$ This largely concurs with the Wittfogelian perception of China as an immobile, underdeveloped society locked into rigid hierarchies.

The problem, however, is that pre-industrial China was far from "precommercial." Recent scholarship demonstrates that Chinese households, wealthy and poor alike, were economically rational and ruthlessly self-interested. ${ }^{13}$ In addition, the economy was significantly market-based, while land ownership was increasingly commoditized and impersonal. ${ }^{14}$ There is, in fact, no real evidence that people agreed on "precommercial" ideals of "permanence in landholding." Quite the opposite, this article presents considerable evidence that property norms, particularly "dian" redemption norms, were generally the product of fiercely self-interested negotiation: Higher-income households tended to resist generous "dian" redemption norms, whereas smallholders were almost

Ellickson, The Cost of Complex Land Titles: Two Examples from China (Yale Law \& Econ. Research Paper no.441, 2011), available at $\mathrm{http} / / /$ papers.ssrn.com/sol3/papers.cfm?abstract_id= 1953207; Taisu Zhang, Property Rights in Land, Agricultural Capitalism, and the Relative Decline of PreIndustrial China, 13 SAN DIEGO INT'L L.J. 129 (2011).

${ }^{8}$ Qing rule over China ran from 1644 to 1912 . The Republican era ran from 1912 to 1949.

99 Philip C.C. Huang, Code, Custom, and Legal Practice in China: The QING and the Republic COMPARED 71-98 (2001); Zhang, supra note 7, at 156-74.

${ }^{10}$ Zhang, supra note 7 , at $156-74$.

${ }^{11} I d$. at 175-86; 18 PUBLICATIONS OF THE SELDEN SOCIETY 143-46 (1904).

${ }^{12}$ Huang, supra note 9, at 74; Melissa MaCAUley, Social Power and Legal Culture: Litigation MASTERS IN LATE IMPERIAL CHINA 234 (1998).

${ }^{13}$ See Lynda S. Bell, Farming, Sericulture, and Peasant Rationality in Wuxi County in the Early Twentieth Century, in ChINESE HISTORY IN ECONOMIC PERSPECTIVE 207, 226-29, 232-39 (Thomas G. Rawski \& Lillian M. Li eds., 1992).

${ }^{14}$ On markets and commercialization, see, e.g., Li BOZHONG, AGRICULTURAL DEVELOPMENT IN JiANGNAN, 1620-1850, at 107-08 (1998); and KENNETH POMERANZ, THE GREAT DIVERGENCE: CHINA, EUROPE, AND THE MAKING OF THE MODERN WORLD ECONOMY 86-87 (2000). On the commoditization of land, see Thomas BuOYe, Manslaughter, Markets AND MORAl ECONOMY: Violent DisPutes OVER PROPERTY RigHTS IN EIGHTEENTH CENTURY CHINA 94 (2000). 
uniformly in favor. A broadly similar situation existed in early modern England, where both large landholders and smallholders pushed for property norms that advanced their economic interests. The difference, however, is that Chinese smallholders were significantly more successful in obtaining favorable institutions than their English counterparts.

But why? If we simply believe - as many scholars continue to do - that Chinese sociolegal hierarchies bred unusually severe class-based political and economic oppression and "oriental despotism," then why were Chinese smallholders comparatively successful in the negotiation of key property institutions? As noted above, large landholders rarely conceded these institutions willingly, but were simply unable to overturn them. In what sense, then, was the Chinese legal tradition truly hierarchical?

This article argues that Chinese property institutions were comparatively egalitarian precisely because Chinese law and society was deeply "hierarchical." This requires, however, that we reject any variation of the old "oriental despotism" thesis in favor of a more nuanced understanding of Chinese sociolegal hierarchies. In other words, the Chinese legal tradition was indeed "hierarchical," but not in the sense that it helped a wealthy political elite dominate and oppress the poorer masses. Although late imperial laws did indeed endorse certain status inequalities between state officials and commoners, they were of limited macro-level significance: Officials were few in number, and wielded little influence in local affairs. Correspondingly, some historians have come to realize that the most important hierarchies in Chinese law and society - those that truly affected every level of socioeconomic life-were instead between senior and junior relatives: between parents and children, uncles and nephews, elder brothers and younger brothers. ${ }^{15}$ The sociopolitical dominance of senior relatives over junior ones was not merely enshrined in formal and customary law, but was probably internalized as a foundational moral principle by most of the Qing and Republican population.

But what even these scholars have missed is that these "Confucian" kinship hierarchies enhanced, rather than undermined, political equality between rich and poor. Their predominance in rural society - compared to the relative "individualism" of early modern English society_was, in fact, the very reason Chinese property norms protected lower-income households more rigorously than corresponding English institutions.

The following pages will demonstrate that the social status and rank of most individuals in Qing and Republican China depended significantly on their generational seniority within their respective patrilineal descent groups. In contrast, the importance of kinship and communal ties in rural English society precipitously declined in late Medieval and early modern times. ${ }^{16}$ The tighter social fabric of rural China was indisputably more "hierarchical"-_elder kinsmen wielded extensive legal and customary authority over younger ones - but also conferred large status benefits on lower-income households: Because status was so closely tied to age and generational seniority, the system guaranteed significant status mobility within most individual lifetimes. People automatically gained status as they aged, theoretically independent of personal wealth.

\footnotetext{
${ }^{15}$ See discussion at infra, pp. _-_.

${ }^{16}$ AlAN MACFARLANE, THE ORIGINS OF ENGLISH INDIVIDUALISM: FAMILY, PROPERTY, AND SOCIAL TRANSITION (1978); David Cressy, Kinship and Kin Interaction in Early Modern England, 113 PAST \& PRESENT 38, 41 (1986); H.R. French \& Richard Hoyle, English Individualism Refuted and Reasserted: the Case of Earls Colne (Essex), 1550-1750, 56 ECON. HIST. REV. 595 (2003).
} 
In practice, of course, wealth remained a valuable social asset, but even so, lowerincome seniors could frequently obtain status and authority quite disproportionate to their wealth. Even this weaker claim is significant in a comparative context: By most accounts, significant landholding was a strict prerequisite for higher status in rural England, leading to the near-monopolization of sociopolitical authority by the wealthy. ${ }^{17}$ The cumulative social status and authority of smallholders and tenants was, therefore, much higher in China than in England.

Higher status naturally led to stronger bargaining positions in the negotiation of property norms. In both early modern China and England, property norms were more often shaped by local custom rather than formal law. In other words, they were generally negotiated within local communities. Differences between Chinese and English property norms reflected, therefore, the different local power balances at play in such negotiations: Because Chinese smallholders and tenants cumulatively possessed higher social status than their English peers, Chinese property norms protected their immediate economic interests far more vigorously than English norms.

This thesis does not postulate the existence of some "Confucian welfare state" 18 in China. The imperial Chinese state did support some social welfare programs - notably disaster relief granaries ${ }^{19}$ - but embraced no sweeping ideology of socioeconomic equality. There is similarly no evidence, as discussed above, to suggest that local economic elites were substantively more sympathetic towards their poorer countrymen or townsmen than English ones. The primary difference was not one of generosity or attitude, but simply that Chinese economic elites were less able to impose their will on poorer households. ${ }^{20}$

The redemption of pawned land was hardly the only area where Chinese property norms were more egalitarian than English ones. For example, Qing and Republican local customs also favored poorer households over richer ones in crucial aspects of tenancy regulation. Most notably, Lower Yangtze customs regularly allowed and protected the right of "permanent tenancy" ("yong dian"), in which landlords lost the right to raise rents or evict tenants. ${ }^{21}$ Early modern English landlords suffered no comparable handicaps and were notoriously ruthless in the eviction of tenants and consolidation of estates. $^{22}$ The model of custom formation presented here may explain, therefore, several key differences between Chinese and English property institutions, although the article can examine only one in detail.

While the primary goal of this article is to explain a major historical phenomenon and revise our understanding of traditional Chinese sociolegal hierarchies, it also

\footnotetext{
${ }^{17}$ KeIth Wrightson, English SocIETy, 1580-1680, at 43 (2003); H.R. French, Social Status, Localism and the 'Middle Sort of People' in England, 1620-1750, 166 PAST \& PRESENT 66 (2000).

${ }^{18}$ On state welfarism in Chinese history, see R. BIN WONG, CHINA TRANSFORMED: HistoriCAL CHANGE AND THE LIMITS OF EUROPEAN EXPERIENCE (1997).

${ }^{19}$ See, e.g., LILliAN M. Li, Fighting FAMINE IN NORTH CHINA (2007).

${ }^{20}$ See discussion at infra, pp. _-_.

${ }^{21}$ E.g., HUANG, supra note 9, at 99-118; KATHRYN BERNHARDT, RENTS, TAXES, AND PEASANT RESISTANCE: THE LOWER YANGTZE REGION, 1840-1950, at 21-27 (1992).

${ }^{22}$ See The Brenner Debate 10-67 (T.H. Aston and C.H.E. Philpin eds., 1987); R.W. Hoyle, Tenure and the Land Market in Early Modern England: Or a Late Contribution to the Brenner Debate, 43 ECON. HIST. REV. 1 (1990). Although scholars involved in the "Brenner Debate" vehemently disagreed over whether landlord aggression could explain the Seventeenth Century Anglo-French economic divergence, all agreed that such aggression was indeed prevalent in England.
} 
connects to a broader theoretical literature on social norms. For decades, sociologists and economists - particularly their respective reincarnations within the legal academy-have debated the roles of culture and historical tradition in the creation of social norms. To crudely summarize a long debate, the former group has generally argued that the societal "internalization" of cultural and moral values plays a crucial role in norm creation, whereas the latter sees norm creation as predominantly a bargaining process between rationally self-interested individuals. ${ }^{23}$ Law and economics scholars point out, surely correctly, that traditional sociological studies often treated cultures as consolidated "operative engines" without carefully considering whether self-interested rationality could explain many phenomena they considered ideological or "cultural." 24 On the other hand, many have criticized rational choice-based theories for failing to satisfactorily reflect the complexity of social reality. ${ }^{25}$

A more recent strand of scholarship, sometimes termed "law and socioeconomics," attempts to bridge the gap between these two approaches by simply acknowledging that some norms are rationally negotiated while others are internalized. ${ }^{26}$ This begs the question, however, of which norms are which, and whether there are predictable patterns of interaction between the two categories. Some have hypothesized the existence of "pyramids of norms," in which higher tier norms, potentially created via internalization of core religious or cultural values, set the parameters within which lower tier norms are rationally negotiated. ${ }^{27}$ A supporting contention is that certain kinds of norms, particularly those governing basic social interactions such as kinship and core religious affinity, are more prone to internalization than explicitly economic norms such as

\footnotetext{
${ }^{23}$ Robert C. Ellickson, Law and Economics Discovers Social Norms, 27 J. OF LEGAL STUD. 537, 542 (1998); Amitai Etzioni, Social Norms: Internalization, Persuasion and History, 34 L. \& Soc. REV. 157, 158 (2000); Richard H. McAdams, Comment: Accounting for Norms, 1997 WISC. L. REV. 625.

${ }^{24}$ Ellickson, supra note 23. For a specific example, see J. MARK RAMSEYER \& ERIC B. RASMUSEN, MEASURING JUDICIAL INDEPENDENCE: THE POLITICAL ECONOMY OF JUDGING IN JAPAN (2003), which applies a political economy methodology to the study of the Japanese judiciary. Their work has been challenged on multiple fronts, including methodological ones. Frank Upham, Political Lackeys or Faithful Public Servants? Two Views of the Japanese Judiciary, 30 L. SOC. INQUIRY 421 (2005); JoHN OweN HALEY, THE SPIRIT OF JAPANESE LAW (2006).

${ }^{25}$ See Robert E. Scott, The Limits of Behavioral Theories of Law and Social Norms, 86 VA. L. REV. 1602 (2000). See also PIERRE BourdieU, THE LOGIC OF PRACTICE (Richard Nice trans., 1990) (developing a theory of "habitus" that counters rational choice theories). Rational choice theories struggle, in particular, to explain how rational individuals desist from free-riding on norm enforcement and adherence. Although certain evolutionary game theory models claim to explain social cooperation under fixed conditions, e.g., Jonathan Bendor \& Piotr Swistak, The Evolution of Norms, 106 AM. J. SociOL. 1493 (2001), those conditions often seem unrealistic: for example, that players interact one-on-one even in an n-person game and possess perfect information. Id. at 1533-34. Some have attempted to bypass these difficulties by suggesting that withholding or conferring esteem is "costless." Richard H. McAdams, The Origin, Development, and Regulation of Norms, 96 Michigan Law Rev. 338 (1997). This, too, seems implausible - reputational injury provokes retaliation just as readily as material injury. Suggestions that people obey or enforce social norms to "signal" future cooperation, e.g., ERIC A. POSNER, LAW AND SOCIAL NoRMS (2000), have also been criticized. See Richard H. McAdams, Signaling Discount Rates: Law, Norms and Economic Methodology, 110 YALE L.J. 625, 643-54, 663-68 (2000).

${ }^{26}$ E.g., Mark A. Edwards, Acceptable Deviance and Property Rights, 43 ConN. L. REv. 457, 464-75 (2010); Etzioni, supra note 23, at 158; Eduardo Moisés Peñalver \& Sonia K. Katyal, Property Outlaws, 155 UnIV. PA. L. REV. 1095 (2007).

${ }^{27}$ E.g., HANS KeLSEN, PURE THEORY OF LAW 193-278 (1989); Amir N. Licht, Social Norms and the Law: Why Peoples Obey the Law, 4 REV. L \& ECON. 715 (2008).
} 
property and contract norms. ${ }^{28}$ This is conceivably because people are usually exposed to the former at a younger age, when personal values are still in their formative stage. ${ }^{29}$

By narrowly defining the content and scope of internalized values, and by laying out the precise mechanisms through which they affect calculations of self-interest, the "pyramids" thesis aspires to provide an empirically testable account of how cultural factors shape social norms. It hopes to solve, therefore, the so-called "Sen's Paradox," referring to Amartya Sen's call for theories of socioeconomic behavior that both "bring in something outside individual choice behavior," but also avoid speaking of "society's "preferences"' in such aggregate terms that no empirical testing is possible. ${ }^{30}$ At the moment, however, very little empirical verification of the "pyramids" thesis exists.

The historical account presented here fills in some of that empirical void. It demonstrates how internalized communal values shaped the negotiation of property norms by institutionalizing the allocation of social status and authority among interested parties. Within this rudimentary "pyramid of norms," "Confucian" kinship hierarchies were the "higher tier" norm that defined the parameters within which self-interested parties negotiated "lower tier" property norms.

Geographically, it makes little sense to compare England with all of China due to the enormous socioeconomic variance between Chinese macroregions. Instead, this article focuses on two comparatively developed coastline regions: the Lower Yangtze and North China. ${ }^{31}$ Temporally, it focuses on the $16^{\text {th }}$ and $17^{\text {th }}$ Centuries for England and the later Qing and Republican eras for China. Most of its Chinese primary sources fall within 1865-1940, a period of relative social stability in most rural localities, despite turmoil on the national political stage. The goal here is to compare societies at similar stages of economic development: both England and the two Chinese macroregions boasted significantly commercialized economies on the cusp of industrialization; ${ }^{32}$ both were predominantly agricultural and self-contained, but had some access to maritime trade ${ }^{33}$ finally, both recognized and protected private property rights through law and custom. $^{34}$ Rigorous analysis and comparison would be impossible without these broad similarities. By the early $18^{\text {th }}$ Century, overseas trade would occupy a much greater share of the English economy, making it significantly less comparable to any Chinese macroregion.

A final word about the use of "egalitarian" in this article: Although the term "egalitarian" may be used to describe any kind of equality-promoting behavior or

\footnotetext{
${ }^{28}$ Robert D. Cooter, Decentralized Law for a Complex Economy: The Structural Approach to Adjudicating the New Law Merchant, 144 U. PENN. L. REV. 1643, 1661-62 (1996); Licht, supra note 27, at 721.

${ }^{29}$ Licht, supra note 27 , at 721 .

${ }^{30}$ Amartya Sen, Internal Consistency of Choice, 61 ECONOMETRICA 495, 498 (1993).

${ }^{31}$ On North China, see PhILIP C.C. HuAng, THE PEASANT ECONOMY AND SOCIAL Change IN NoRTH ChINA (1985); KeNNETH PoMERANZ, The MAKING OF A HinTERLAND: STATE, SOCIETY, AND ECONOMY IN InLAND NORTH CHINA, 1853-1937 (1993). On the Lower Yangtze, see LI, supra note 14.

${ }^{32}$ See supra note 14

${ }^{33}$ For the relative unimportance of trade to the early modern English economy, see RALPH DAVIS, THE INDUSTRIAL REVOLUTION AND BRITISH OVERSEAS TRADE 63 (1979). Cf. The Rise of Europe: Atlantic Trade, Institutional Change, and Economic Growth, 95 AM. ECON. R. 546 (2005), which argues that trade was institutionally important even if statistically modest.

${ }^{34}$ See Madeleine Zelin, A Critique of Rights of Property in Prewar China, in CONTRACT AND PROPERTY IN EARLY MODERN CHINA 17 (Madeleine Zelin, Jonathan K. Ocko \& Robert Gardella eds., Stanford Univ. Press 2004).
} 
policy, ${ }^{35}$ within this article's context, it specifically describes institutions and actions that promote the political and economic interests of lower-income households. It is also used in a purely descriptive sense, without ideological connotations attached.

Part One discusses common assumptions about sociolegal "hierarchy" in early modern China. Part Two outlines some examples where Chinese property norms were unusually protective of smallholders, drawing comparisons with corresponding English institutions that favored the economic interests of higher-income households. Part Three unpacks a model of social norm negotiation that explains why the existence of "Confucian" social hierarchies actually enhanced egalitarianism in property institutions. Part Four, the article's empirical core, tests this model against a wide array of historical data, including court cases, contracts, rural surveys, and lineage registries. The Conclusion further discusses the theoretical significance of these findings.

\section{Part One: Hierarchy and Law in Pre-Industrial China}

The argument that law and custom in imperial China was "hierarchical" is as old as the field of Chinese legal history. Insofar as scholars even acknowledged China had "law," 36 they rarely failed to describe that "law" as, more or less, "a moral code calling for inequality and hierarchy," 37 and therefore a tool of political control that could not lead to genuine "rule of law." 38 For many, the study of Chinese law and custom was, and remains, no more than the "the scholarly study of obsequious submission to authority and hierarchy." ${ }^{39}$ The many logical problems with that reasoning aside, the more fundamental question is: "hierarchical" in what sense?

"Hierarchy" is an analytically useless term unless it is further specified and elaborated: Hierarchy of whom over whom? Under what conditions? With what kinds of privileges? Although vast numbers of scholars have made the "imperial Chinese law and society were hierarchical" argument, few have addressed these questions with detail or nuance. For a very long time, the dominant image of Chinese legal hierarchies was simply some version of "oriental despotism" and class oppression: Law and local custom alike were created by a narrow class of elites who utilized institutions at all levelsincluding, but not limited to, unfair advantages in government recruiting, uneven tax duties, and favorable property norms - to protect their core self-interests, largely to the political and economic detriment of other classes. ${ }^{40}$ As one legal article stated, "[f]or

\footnotetext{
${ }^{35}$ Egalitarianism (Stanford Encyclopedia of Philosophy), http://plato.stanford.edu/entries/egalitarianism/ (last visited March 7, 2013) ("An egalitarian favors equality of some sort: People should get the same, or be treated the same, or be treated as equals, in some respect.").

${ }^{36}$ This was disturbingly rare even a few years ago. See William P. Alford, Law, Law, What Law?: Why Western Scholars of Chinese History and Society Have Not Had More to Say about Its Law, 23 MODERN CHINA 398 (1997); Teemu Ruskola, Legal Orientalism, 101 MicH. L. REV. 179 (2002).

${ }^{37}$ Ruskola, supra note 1 , at 2531.

${ }^{38}$ See, e.g., RANDAll PEERENBOOM, CHINA'S LONG MARCH TOWARD RULE OF LAW 46 (2002); Tom Ginsburg, Confucian Constitutionalism? The Emergence of Constitutional Review in Korea and Taiwan, 27 LAW \& SOC. INQUIRY 763, 767 (2002) (summarizing previous literature); Haley, supra note 1, at 915.

${ }^{39}$ STEPHENS, supra note 2.

${ }^{40}$ See sources cited at supra note 2; ACEMOGLU \& ROBINSON, supra note 4; UNGER, supra note 1 (describing Chinese sociolegal hierarchy as class-based); Patricia Ebrey \& James Watson, Introduction, in
} 
centuries, Chinese concepts of property rights were rooted in strongly autocratic Confucian doctrine that enshrined and vindicated hierarchy, authority and inequality.",41 For the most part, this remains the academic dogma in mainland China, where major legal history narratives almost universally decry the "feudal" and "oppressive" nature of imperial institutions. ${ }^{42}$

Such oppression purportedly generated severe wealth disparity, lack of social mobility, and, ultimately, relative economic decline: elite domination stifled free entrepreneurialism and technological innovation, created tremendous social unrest, and left the rural economy vulnerable to natural disasters. ${ }^{43}$ Insofar as Chinese immigrants have been economically successful in other parts of the world, their success supposedly stems from the disintegration of traditional sociopolitical hierarchies and greater mobility in immigrant communities. ${ }^{44}$

The image of a dominant elite ruling the country is not entirely unsubstantiated: Legal culture, even in the Ming and Qing, certainly privileged certain social groups over others. The emperor was largely beyond formal legal sanction, and the law afforded special statuses, including exemption from most taxes and legal prosecution, to his extended family. ${ }^{45}$ More generally, Manchu bannermen possessed economic privileges not available to Han Chinese throughout the Qing, ${ }^{46}$ while high-level national examination degree holders enjoyed significant political and social advantages over lower level scholars or non-degree holders. ${ }^{47}$

To portray these privileges as the symptoms of class-based institutional oppression is, however, to exaggerate the sociopolitical clout of these elites. They occupied, first of all, a tiny portion of the population. Due to stubborn government reluctance to expand examination degree quotas in proportion to population growth, degree-holders of any level were extremely rare in the Qing-far lower than one percent of total population. ${ }^{48}$ Imperial clan members were, of course, even rarer. Even bannermen did not exceed a few percentage points of the total and, in any case, had lost much of their privileged status by the Nineteenth Century. ${ }^{49}$ To put this in comparative

KINSHIP ORGANIZATION IN LATE IMPERIAL CHINA, 1000-1940, at 1-2 (Patricia Ebrey \& James Watson eds., Univ. of California Press, 1986).

${ }^{41}$ Paul Cantor \& James Kraus, Changing Patterns of Ownership Rights in the People's Republic of China: A Legal and Economic Analysis in the Context of Economic Reforms and Social Conditions, 23 VAND. J. TRANSNAT'L L. 479, 483 (1991).

${ }^{42}$ See ZHANG, supra note 1; Chen, supra note 1; Weifang He, The Judicial System and Governance in Traditional China, in THE RULE OF LAW: PERSPECTIVES FROM THE PACIFIC RIM 91 (Mansfield Center for Pacific Affairs ed. 2000)

${ }^{43}$ See sources cited at supra note 4.

${ }^{44}$ LAWrence E. HARrison, Who Prospers: How CUltural VAlues Shape ECONOMiC AND Political SuCCESS 15 (1992); Amy L. Chua, Markets, Democracy, and Ethnicity: Toward A New Paradigm For Law and Development, 108 YALE L.J. 1, 30-31 (1998).

${ }^{45}$ ZHANG, supra note 1, at 84-112; Chen Peipei, Qingdai Falü Tequan Yanjiu [A Study of Legal Privileges in the Qing] (2007) (unpublished M.A. thesis, Anhui University), available at http://cdmd.cnki.com.cn/Article/CDMD-10357-2007193110.htm.

${ }^{46}$ See Mark C. Elliot, The Manchu Way: The Eight BanNers and Ethnic Identity IN Late IMPERIAL CHINA 175-274 (2001).

${ }^{47}$ See Ch'U Tung-TSu, LOCAL GOVERnMENT IN CHINA UNDER THE Ch'ING 168-92 (1962).

${ }^{48}$ Benjamin A. Elman, Political, Social, and Cultural Reproduction via Civil Service Examinations in Late Imperial China, 50 J. ASIAN STUD. 1, 14-15 (1991).

${ }^{49}$ MATTHEW H. SOMMER, SEX, LAW AND SOCIETY IN LATE IMPERIAL CHINA 8 (2000). 
perspective, titled nobility comprised perhaps two percent of early modern England's population, ${ }^{50}$ to say nothing of the far more numerous landed gentry. More importantly, the Qing state was very limited: its small size severely dampened tax collection and law enforcement powers, forcing local officials to leave most administrative and rulemaking duties to communal, guild or kinship based self-governance. ${ }^{51}$

Perhaps aware of these flaws in the traditional "elite despotism" thesis, scholars have increasingly pointed to "Confucian" kinship institutions as a more comparatively significant source of sociopolitical hierarchy ${ }^{52}$ : Virtually all segments of Qing society recognized systematic inequalities between different family members. ${ }^{53}$ Parents naturally occupied a higher sociolegal position than their offspring, as did uncles over nephews, and elder brothers or cousins over younger ones. Physically assaulting a parent, for example, was punishable by death, whereas beating one's child was perfectly acceptable. Even disobedience or rudeness to a senior relative could constitute a punishable offense, if not by law then by lineage self-regulation or local custom. Unsurprisingly, major socioeconomic decisions were generally made by the household patriarch in consultation with other senior male members of his kinship group. Relatives also enjoyed certain economic privileges over non-relatives: Many local customs dictated, at least nominally, that landowners offer their land to relatives first when exploring sale options, and only sell to non-relatives if those offers are unsuccessful. ${ }^{54}$

Kinship hierarchies retained much of their vitality even after the Qing's collapse. Republican legal codes narrowed the range of privileges afforded to senior relatives, but did not eliminate them altogether. ${ }^{55}$ For example, killing or assaulting a senior relative continued to be punished more severely than usual homicide or assault. ${ }^{56}$ More importantly, the great majority of local communities continued to recognize and enforce traditional kinship hierarchies throughout the Republican era, and many do so even today. 57

Despite their immense historical importance, how Confucian kinship hierarchies affected society-wide distributions of wealth and sociopolitical status is hardly understood, if at all. Most pieces simply ignore the issue. Scholars of considerable reputation but questionable exposure to Chinese history, most famously Jürgen Habermas, have attempted to dismiss the compatibility of kinship institutions with economic and

\footnotetext{
${ }^{50}$ M.L. Bush, The ENGLish ARISTOCRACY: A COMPARATIVE SYNTHESIS 35 (1984).

${ }^{51}$ See Ch'u, supra note 47; BRAdLEY W. REED, TALONS AND TEETH: COUNTY ClERKS AND RunNERS IN THE QING DYNASTY (2000).

${ }^{5}$ See, e.g., William P. Alford, The Inscrutable Occidental: Roberto Unger's Uses and Abuses of the Chinese Past, 64 TeXAs L. REV. 915, 931 (1986); Avner Greif \& Guido Tabellini, Cultural and Institutional Bifurcation: China and Europe Compared, 100(2) AM. ECON. REV.: PAPERS \& PROCEEDINGS 1 (2010); Teemu Ruskola, The East Asian Legal Tradition, in THE CAMBRIDGE COMPANION TO Comparative LaW 257, 263-64 (Mauro Bussani \& Ugo Mattei eds., Cambridge Univ. Press 2012).

${ }^{53}$ See ZHANG, supra note 1, at 113-35; 8 ZHONGGUO FAZHI [HISTORY OF LAW IN CHINA, hereinafter TONGSHI] 208, 256-57, 508 (Zhang Jinfan ed., 1999).

${ }^{54}$ TONGSHI, supra note 53, at 267-68.

${ }^{55}$ Liu Guoqiang, Qingmo Minguo shiqi xingfadian jianshe zhong qinshu lunli guanxi de chuancheng yu biange [Continuity and Change in the Treatment of Kinship Ties in Late Qing and Republican Criminal Codes], 2012(4) DAODE YU WENMING 67.

${ }^{56} I d$.

${ }^{57}$ FENG ERKANG, 18 SHIJI YILAI ZHONGGUO JIAZU DE XIANDAI ZHUANXIANG [THE MODERN TURN OF CHINESE LINEAGES SiNCE THE $18^{\mathrm{TH}}$ CENTURY] 214-313 (2011).
} 
social "modernity" in broad, but clearly misguided, strokes: Because familial hierarchies are supposedly incompatible with normative certainty and predictability, "Asiatic societies cannot participate in capitalistic modernization without taking advantage of the achievements of an individualistic legal order."58 Others, particularly mainland Chinese scholars, attempt to conflate kinship hierarchies with the despotism thesis, arguing that the former encouraged habitual submission to authority that supported the latter. ${ }^{59}$

There may be some truth to that, but as this Article will demonstrate, whether in the creation of property and contract institutions or in the local distribution of political authority, kinship hierarchies weakened class and wealth-based oppression. In the very limited sense that they recognized status differences between different individuals, kinship institutions were indeed "hierarchical." From a broader perspective, however, the term "hierarchical" masks some fairly unique characteristics: Unlike in other social hierarchies that tied status strictly to heritage, including most feudal or caste-based societies, the category of privileged persons was very fluid under Confucian norms. As one aged and had children, he or she automatically gained legal and customary authority over younger generations. Normatively, wealth did not affect status within kinship groups. A wealthy nephew owed the same sociolegal obligations to a penniless uncle as a penniless nephew to a wealthy one.

However counterintuitively, these kinship hierarchies should theoretically have promoted, rather than damaged, status mobility, simply because everyone aged, which automatically boosted their status and rank both within and beyond their kinship network. This latter point requires some elaboration: Most kinship networks were of considerable size - several dozen households in North China, and considerably more than that in the Lower Yangtze - and, therefore, carried enough collective clout that high rank within the kinship network generally translated also into relatively high status beyond its borders.

Because kinship hierarchies were theoretically disconnected from wealth, they should have empowered large numbers of low-income but high-seniority individuals against their wealthier kin and, therefore, should have helped level the cumulative sociopolitical balance between rich and poor. In crude terms, even the wealthiest individuals probably had poorer relatives who were of similar or higher generational seniority. It was, hypothetically, a system were systematic individual inequality led to macro-level equality between rich and poor.

As the remainder of this Article will demonstrate, even in practice, Confucian social hierarchies generated enough status mobility to inject much socioeconomic egalitarianism into China's property and contract institutions - in fact, significantly more than what one finds in early modern English norms. Late imperial and Republican property customs often offered superior protection to lower-income households than comparable institutions in England. More importantly, they did so precisely because kinship hierarchies remained strong in China, whereas English society had become "individualistic." This hardly meant that affluent Chinese households harbored greater sympathy towards poorer kinsmen, but rather that kinship hierarchies facilitated cumulative status equality amongst even the most self-interested of people.

\footnotetext{
${ }^{58}$ HABERMAS, supra note 4. See also Greif \& Tabellini, supra note 52, at 5 (questioning whether kinship institutions might affect China's "capacit[y] in bringing about the modern economy and adjusting to it").

${ }^{59}$ See Chen, supra note 1; ToNGSHI, supra note 53, at 257-60, 264-66.
} 


\section{Part Two: The Relative Egalitarianism of Chinese Property Institutions}

For such a "hierarchical" legal culture, Chinese laws and customs could often be astonishingly "soft" towards lower income households. The full extent of this is best appreciated - perhaps only appreciated, considering the virtual impossibility of imagining what "wealth-neutral" property norms look like - in a comparative context. The choice here to compare Chinese property institutions with early modern English ones draws from both the intellectual appeal of the "Great Divergence" literature ${ }^{60}$ and, as seen below, from the innate analytical cogency of that comparison.

This Article focuses primarily on norms that regulated, for lack of a better term, "land pawning" - transactions that allowed a cash-needy landholder to collateralize his holdings for a large sum, equal to most or even all of its full market value. Such instruments were crucial to the development of mature land markets and monetary liquidity in early modern economies, where land was the prime source of capital and livelihood, and therefore sold with considerable reluctance. As the author has discussed elsewhere, the primary instrument for land collateralization - in fact, the only instrument commonly available to landholders - was the mortgage in early modern England, and the "dian" ("conditional sale") in Qing and Republican China. ${ }^{61}$

Compared to modern Anglo-American mortgages, the "classic mortgage" of Sixteenth and Seventeenth Century England was a duller instrument. Modern mortgages allow, of course, repayment schedules of up to several decades, generally permit the mortgagor to maintain possession of the property, and, in cases of default, arrange foreclosure auctions to raise the collateral's full market value. ${ }^{62}$ The classic mortgage was not nearly as lenient to mortgagors: First, mortgagees were allowed to possess the land while waiting for repayment. ${ }^{63}$ More importantly, most local customs dictated that mortgagors must repay their debts within a very short time-frame-generally six months to a year after the initial conveyance, or the mortgagees would automatically obtain full ownership of the collateral. ${ }^{64}$

Up until the early Eighteenth Century, Common Law courts enforced these customary deadlines quite ruthlessly, so much that Chancery felt compelled to aid beleaguered mortgagors by establishing "the equity of redemption," allowing judges to extend redemption deadlines and demand foreclosure auctions upon final default. ${ }^{65}$ These reforms did not, however, harden into established doctrine until the midEighteenth Century, and even then, their prominence over Common Law rules was questionable. $^{66}$

The cash-needy landowner in early modern China faced far more favorable institutional conditions. Most Qing and Republican land transactions were not permanent

\footnotetext{
${ }^{60}$ See especially POMERANZ, supra note 14.

${ }^{61}$ Zhang, supra note 7.

${ }^{62}$ DAvid A. Schmudde, A Practical Guide to Mortgages AND LiEnS 7 (2004).

${ }^{63}$ See William BlackStone, 2 COMMENTARIES ON THE LAWS OF ENGLAND 157-58 (Univ. of Chicago Press, 1979); A.W.B. SiMPSON, A HistoRY OF THE LAND LAW 242-43 (1986).

${ }^{64}$ Zhang, supra note 7, at 182-86.

${ }^{65}$ David Sugarman \& Ronnie Warrington, Land Law, Citizenship, and the Invention of "Englishness": The Strange World of the Equity of Redemption, in EARLY MODERN CONCEPTIONS OF PROPERTY 111, 113 (John Brewer \& Susan Staves eds., 1996).

${ }^{66}$ See Burgess v. Wheate (1759), 96 Eng. Rep. 67, 1 Black. W. 123 (K.B.); Sugarman \& Warrington, supra note 65 , at 117 .
} 
sales, but rather "dian" ("conditional") sales, where the "dian" "seller" conveyed land to the "buyer" for 60 to 80 percent of the property's full market value, but retained the right to redeem at zero interest. ${ }^{67}$ The "dian" buyer's interest in lending money under such an arrangement was not monetary interest, but whatever profit the land could yield before the seller redeemed. He was, therefore, often protected by contractually-established "guaranteed usage periods" ("xian") of one or more years, during which the seller could not redeem. ${ }^{68}$ In addition, he could obtain full ownership of the land if the "dian" seller agreed to convert the transaction into a permanent sale ("mai"), upon which the seller would receive "additional payments" ("zhaotie") that made up the difference between the original transaction price and the land's present market value. ${ }^{69}$

Most significantly, "dian" customs generally allowed "dian" sellers to retain redemption rights ad infinitum. As one local custom stated, "dian" sales "could be redeemed after several hundred years, and the price of redemption would always remain the same."70 Similar customs were commonplace throughout China's core regions, particularly North China and the Lower Yangtze. ${ }^{71}$ Many explicitly forbid the original contract from setting any redemption deadline. Others allowed redemption rights to be exercised "any time after the guaranteed-usage period's expiration." These rules were not for show: Under their influence, very few "dian" contracts attempted to establish redemption deadlines, and most "dian" sales were apparently redeemed at some point. ${ }^{72}$ Local legal archives contain, moreover, numerous cases where a "dian" seller or his descendants attempted to redeem after astonishingly long periods-sometimes a century.

This was an institutional arrangement rife with social tension. During the decades that often passed between "dian" sale and redemption request, families might move, original contractors might die, or usage rights might be transferred to a third party. The swelling volume of related disputes brought before local courts eventually pushed the central government into action: It made several attempts to limit the redemption window of "dian" sales, ordering first in the Qing Code that all contracts must explicitly indicate whether they were permanent sales or "dian" sales, ${ }^{73}$ and then, in the 1758 Board of Finance Regulations, that regular "dian" sales must be redeemed within ten years or be converted to a permanent sale, with at most a one-year extension. ${ }^{74}$

Enforcement of these legal rules, however, was weak. A survey of local case archives from the later Qing suggests that the great majority of redemption deadline cases - where the "dian" buyer refused to allow redemption because too much time had passed since the original contract - were eventually settled via external mediation, often at the court's behest. ${ }^{75}$ Due to their lack of coercive authority, local magistrates were hesitant to formally adjudicate cases where central laws and regulations conflicted with

\footnotetext{
${ }^{67}$ Zhang, supra note 7 , at $156-57$.

${ }^{68} I d$.

${ }^{69} \mathrm{Id}$.

${ }^{70}$ Minshangshi Xiguan DiaOcha BaOgaOlu [RESEARCH REPORT ON CIVIL AND COMMERCIAL CUSTOMS] 505 (Sifa Xingzheng Bu ed., 1930).

${ }^{71}$ Zhang, supra note 7 , at 161-63.

${ }^{72}$ Id. at $161,192-93$.

73 DA QING LÜ LI [THE GREAT QING CODE] [hereinafter DQLL] § 95-107 (1905).

${ }^{74} 1$ QINGDAi GE BUYUAN ZELI: QINDING HUBU ZELI (QIANLONG CHAO) [REGULATIONS OF QING BoARDS AND MinisTRIES: IMPERIAL BOARD OF FINANCE REGULATIONS (QIANLONG ERA)] 83, 148-49 (Fuchi Shuyuan ed., 2004).

${ }^{75}$ Zhang, supra note 7, at 168-74.
} 
local custom. This is unsurprising, as historians have long emphasized the serious weakness of the Qing state in local governance, especially in the regulation of commercial activity. ${ }^{76}$

By the Republican era, the government had basically admitted that Qing rules against excessive redemption were unenforceable: early Republican-era governments extended the national deadline for land redemption to sixty years, a clear concession to local custom. ${ }^{77}$ After 1929, the newly-victorious Nationalist government attempted to impose a thirty year deadline nationwide, ${ }^{78}$ but surveys of Northern Chinese peasants conducted a decade later suggest that their efforts were ineffectual: Most peasants had no knowledge of it, and most who did believed that no one followed it. ${ }^{79}$

For "dian" sellers, these customary norms offered tremendous advantages with very limited downside. The most obvious evidence of this is that, in the variety of disputes examined below, "dian" sellers universally argued in favor of these norms, whereas "dian" buyers were almost always opposed. This is unsurprising: Land was, to most rural residents in these early modern times, the single most valuable kind of property, not only because of its high market value but also because it was the foundation of most economic production. As various Qing and Republican era sources repeatedly claim, landowners generally sold land only when financial conditions made it absolutely necessary, and therefore usually preferred redeemable "dian" sales to permanent ones. ${ }^{80}$ Under these conditions, an institutional framework that effectively eliminated the danger of default and seizure was highly attractive to cash-strapped landowners.

"Dian" sellers did lose some contractual freedom under this arrangement, but not much. They could not contractually establish a deadline for redemption even if they wanted to. Removing the possibility of default did not, however, remove the possibility of permanent alienation: If, after the original contract, the "dian" seller ever wished to permanently convey his land, he could simply request an additional payment ("zhaotie"), converting the "dian" sale into a permanent one at full market value. ${ }^{81}$ A more serious concern might be that the inability to impose redemption deadlines would be priced into "dian" prices, which were, in fact, only 60 to 80 percent of the land's full value. Because, however, most "dian" sales were made under considerable financial stress, a lower "dian" value, so long as it covered immediate needs, was a far smaller concern than obtaining extended redemption rights. Moreover, there were ways to negotiate higher "dian" prices: the seller could simply grant a longer guaranteed-usage period ("xian"), which gave buyers greater security and larger returns.

On the other hand, customary law did "dian" buyers few favors. The constant danger of redemption after the guaranteed-usage period's expiration seriously decreased

\footnotetext{
${ }^{76}$ See sources at supra note 51

776 FALING JILAN [EDITED COLLECTION OF LAWS AND REGULATIONS] 179-80 (Sifa Bu ed. 1917).

${ }^{78}$ ZHONGHUA Minguo Minfa DiAn [CIVIL CODE OF THE REPUBLIC OF CHINA], arts. 912, 924 (1929).

${ }^{79}$ See discussion at infra, pp. _-_.

${ }^{80}$ For China, see, e.g., HUANG, supra note 9, at 73; Madeleine Zelin, The Rights of Tenants in Mid-Qing Sichuan: A Study of Land-Related Lawsuits in the Baxian Archives, 45 J. ASIAN STUD. 499, 515 (1986).

${ }^{81}$ Land prices rose between 1650 and 1835, and between 1860 and 1930 as well, further decreasing the economic risk involved. On 1650-1835, see Li Wenzhi, Lun Yapian Zhanzheng qian Dijia he Goumai Nian [On Land Prices and Purchase Years Before the Opium War], 1988(2) ZHONGGUO SHEHUI JINGJI SHI YANJIU [STUD. OF SOC. \& ECON. HIST.] 1. On Lower Yangtze land values, see BERNHARDT, supra note 21, at 248-49.
} 
the land's value to buyers by discouraging both long-term investments to improve the land and use of the land as a reliable source of capital or collateral. ${ }^{82}$ The tremendous attractiveness of "dian" customs to potential land sellers also drained the supply of permanent land sales, further exacerbating the difficulty of secure land accumulation. ${ }^{83}$ Despite all this, the demand for "dian" sales remained high during times of relative peace, driven by a combination of population growth, commercialization, and nascent industrialization. All in all, "dian" selling was a strikingly low-risk affair in early modern China, especially when compared to the perils of English mortgaging.

Not surprisingly, the economic identities of creditors and debtors were broadly similar across the two countries: both mortgagors and "dian" sellers were generally much poorer compared to mortgagees and "dian" buyers. The historical literature is remarkably consistent on this: Few would dispute that the Sixteenth and Seventeenth Centuries were, in England, a time of massive wealth and land concentration from small tenants and lesser yeomen into the hands of large capitalist farmers. ${ }^{84}$ The process, in its earlier stages, relied primarily on land transactions - sales and mortgages, driven on the supply side by falling grain prices and shrinking agricultural profit margins - rather than enclosure. $^{85}$ Although China did not experience any comparable flood of land engrossment, its overall pattern of land transaction was nonetheless from poorer households to wealthier ones. In one fairly typical North China village, for example, around $85 \%$ of "dian" sellers during the later 1930s possessed less land than the village average, and nearly $40 \%$ possessed less than a third of that average. In contrast, less than $3 \%$ belonged to the top $25 \%$ of landowners. ${ }^{86}$ Additional circumstantial evidence can be found in contract collections from late Qing and Republican era Zhejiang Province: They commonly show one household conditionally buying multiple parcels from a wide assortment of sellers, which certainly suggests that a few relatively wealthy households were aggressively acquiring land from numerous poorer ones. ${ }^{87}$

The institutional protection of "dian" sellers was, therefore, also the protection of poor against rich. Likewise, the harsh treatment of mortgagors in English custom usually meant harsh treatment of smallholders and tenants in favor of aggressively expanding gentry and capitalist farmers. Indeed, as I have argued elsewhere, the institutional contrast between "dian" and mortgage significantly explains why landholding was more equitable in China than in England ${ }^{88}$ : "Landlords" and "large farmers" owned only 40 to

\footnotetext{
${ }^{82}$ See Ellickson, supra note 7.

${ }^{83}$ See Zhang, supra note 7, at 187-94.

${ }^{84}$ See Robert C. Allen, EnClosure And the YeOMAn: THE AgriCultural DeVElopment Of THE SOUTH MidLANDS 1450-1850 (1992); Leigh Shaw-Taylor, The Rise of Agrarian Capitalism and the Decline of Family Farming in England, 65 ECON. HIST. REV. 26 (2012).

${ }^{85}$ See J.V. Beckett, The Decline of the Small Landowner in Eighteenth-and Nineteenth-Century England: Some Regional Considerations, 30 AGRI. HIST. REV. 97, 98-100 (1982) (summarizing existing literature).

863 CHugOKu Noson KANKo CHOSA [INVESTIGATION OF RURAL ChINESE Customs] [hereinafter MANTETSU SURVEYS] 5 (Committee for the Publication of the Rural Customs and Practices of China ed., Iwanami Shoten Press 1958). See also 4 MANTETSU SURVEYS, at 218 (showing a similar situation in a different village).

${ }^{87}$ See QINGDAI NingBo QIYUE WENSHU JIJIAO [QING CONTRACTS FROM NINGBO] [hereinafter NingBO CONTRACTS] (Wang Wanying ed., Tianjian Guji Press 2008) (showing Mao Kunshan “dian”-purchasing land from over 100 different sellers), 3 SHICANG QIYUE [SHICANG CONTRACTS] (Cao Shuji ed., Zhejiang Univ. Press 2010) (showing Que Yuqing “dian”-purchasing land from over 50 sellers).

${ }^{88}$ Zhang, supra note 7.
} 
50 percent of arable land throughout the later Qing and Republic, and managed less than 15 percent. ${ }^{89}$ In comparison, conventional estimates of landownership by the English royalty, nobility and gentry range from 65 to 75 percent of total land in 1690, 85 in 1790, and 90 by $1873 . .^{90}$ Moreover, "capitalist," managerial farms dominated agricultural production as early as 1700 , largely by squeezing out smallholders and converting them into paid labor. "Dian" redemption norms were instrumental in preventing the largescale centralization of land in China, whereas mortgage laws were similarly important in facilitating the very same process in England.

Land redemption was not the only major area of property regulation where Chinese local customs were significantly more accommodating towards the economically disadvantaged. The same characterization also applies to customs and laws governing tenant eviction and rent adjustment: Since at least the Eighteenth Century, local customs across the Lower Yangtze and South China recognized rights of "permanent tenancy" ("yong dian"), an endless tenancy that permitted eviction or rent-raising only if unpaid rents had exceeded the property's full value. ${ }^{91}$ Responding to petitions by frustrated landlords, several provinces enacted regulations outlawing such arrangements, but generally failed to enforce them. ${ }^{92}$

The closest analogy to permanent tenancy in early modern England was probably the copyhold of inheritance. Established by manorial custom rather than the Common Law, such tenancies usually had no fixed term, paid only a nominal rent, could be inherited, sold, mortgaged or subleased just as freehold land, and were not subject to direct evictions. Creation of copyholds, however, had progressively slowed during the Fifteenth and Sixteenth Centuries, and had largely vanished by the Seventeenth. ${ }^{93}$ Quite the opposite, landlords encumbered by copyholds were busy revoking copyhold rights, usually by unilaterally raising rents or inheritance and conveyance fees. ${ }^{94}$ Copyholders who converted their holdings into leasehold land under such pressure became tenants in the modern sense: they held only for a fixed term of years, and could not pass the tenancy to their heirs without the landlord's express approval.

How, then, can we tally the stronger economic egalitarianism of Chinese property norms, which came at significant inconvenience and cost to the wealthiest segments of society, with the common perception of Chinese law and custom as fundamentally hierarchical and unequal? Could a legal framework that embraced innate individual inequality also promote cumulative economic equality? It depends, as alluded to in Part One, on which concept of hierarchy we employ_class-based despotism or kinshipbased - and how we unpack their sociopolitical implications.

\footnotetext{
${ }^{89}$ Joseph W. Esherick, Number Games: A Note on Land Distribution in Prerevolutionary China, 7 MODERN CHINA 387, 397, 405 (1981).

90 J.V. Beckett, The Pattern of Landownership in England and Wales, 1660-1880, 37 ECON. HIST. REV. 1 (1984).

${ }_{91}^{9}$ See discussion at supra note 21.

92 See Huang, supra note 21.

${ }^{93}$ R.W. Hoyle, Tenure and the Land Market in Early Modern England, 43 ECON. HIST. REV. 1, 7-12, 17-18 (1990).

${ }^{94}$ BRENNER DEBATE, supra note 22, at 10-63; ERIC KERRIDGE, AGRARIAN PROBLEMS IN THE SIXTEENTH CENTURY AND AFTER 36-37 (1969); Hoyle, supra note 93 (placing the start of conscious landlord encroachment at around 1550).
} 
If, in accordance with some variety of the traditional "oriental despotism" thesis, Chinese institutional hierarchies simply enshrined the dominance of wealthy political elites, then it is very strange why these elites would establish or tolerate property norms that seriously damaged their own economic interests. Certainly they might occasionally compromise with lower-income groups to foster goodwill and win prestige, in much the same way that feudal European lords were expected to treat their subjects with some benevolence, but that is hardly the case here. Instead, as discussed both above and below, the spirited but futile attempts of central officials and local economic elites to reign in "dian" redemption customs and eliminate permanent tenancy suggest not only elite opposition to these norms, but also an inability to abolish them.

All this urges us to cast aside the understanding of Chinese sociolegal hierarchy as "oriental despotism" or the dominance of wealthy elites: the state and the wealthiest echelons of society simply were not that powerful. If the concept of "Chinese" institutional hierarchy is to substantively survive, it must focus on the more complex social hierarchies within kinship groups and families. When unpacked properly, not only are kinship hierarchies consistent with the relative egalitarianism of Chinese property norms, they actually explain it.

\section{Part Three: Models and Theories}

Among legal historians, the traditional explanation for the customary protection of "dian" redemption rights in pre-industrial China has been exceedingly straightforward: They derived directly from a moral and ideological embracement of "permanence in landholding" ideals in "precommercial" societies. ${ }^{95}$ Some believe that interminable redemption rights were a natural normative component of premodern economies: the prevalence of subsistence agriculture was mutually reinforcing with mores that shamed the loss of ancestral property and glorified the stable descent of land from generation to generation. ${ }^{96}$ Others suggest that Chinese peasants simply possessed a strong sentimental attachment to land and were unwilling to lose $\mathrm{it}^{97}$ - this may have reflected, of course, the higher socioeconomic value of land in pre-industrial societies.

The evidence presented in support of these arguments, however, is thingenerally no more than vague moralizing by literati on the importance of land. The higher economic value of land in preindustrial societies, on the other hand, pushed in opposite directions: Apart from encouraging landowners to retain their properties, it also encouraged them to aggressively acquire new property. The stubbornly high demand for land sales, both permanent and "dian," from around 1870 to the 1930s certainly suggests that the latter dynamic was consistently at work in times of relative peace, ${ }^{98}$ despite the prevalence of highly burdensome "dian" customs. The attractiveness of landownership alone is, therefore, an inadequate explanation for the existence of those customs. Consider also the comparison with England: Early modern English landowners, too, had a strong sentimental and economic attachment to land, made all the more powerful by the

\footnotetext{
95 See sources at supra note 12.

${ }^{96}$ HUANG, supra note 9 , at 74.

${ }^{97}$ MACAULEY, supra note 12.

${ }^{98}$ See discussion at supra note 81 .
} 
dependency of sociopolitical status on landed wealth, ${ }^{99}$ but this clearly did not prevent their customs from limiting redemption windows and tenancy security. If anything, the strong psychological premium placed on landownership actually encouraged larger landowners to champion such limitations.

Moreover, the characterization of early modern Chinese society as "precommercial" has been severely challenged in recent scholarship: Studies of grain price fluctuations within and across macroregions show that large portions of the rural economy had become market-integrated. This directly contradicts older assumptions about the dominance of subsistence agriculture. Evidence of market integration is robust not only in core macro-regions such as the Lower Yangtze and North China, but also in frontier regions such as Gansu. ${ }^{100}$ The Lower Yangtze, of course, boasted bustling commodity markets that affected a significant majority of households. Perhaps 15 percent of the rural workforce was completely non-agricultural, and most agricultural households also engaged in some textile or craft production. ${ }^{101}$

Unsurprisingly, commercialization went hand-in-hand with individual economic rationality: most households were both calculating and resourceful. They invested in land when profitable, employed excess labor in non-agricultural production, reacted swiftly to fluctuations in land or commodity prices, and, as demonstrated below, tirelessly promoted economic institutions and norms that favored their own interests. ${ }^{102}$ Certainly the existence of strong lineages promoted communal solidarity, but even within lineages, households often clashed over property, debt, and the rules that governed them. ${ }^{103}$ It is unclear how such a commercialized society could have sustained moral ideals of "permanence in landholding."

In fact, it probably did not. The evidence presented below strongly suggests that such "ideals" were embraced only by those who could economically benefit from them, ${ }^{104}$ and that "dian" and permanent tenancy customs were the result of intense and prolonged negotiation between highly self-interested parties, rather than simple moral derivatives of "precommercial" ideals. Bargained equilibriums could emerge where moral uniformity did not. As a general theoretical matter, individuals may choose to tolerate undesirable property norms for many reasons: to signal willingness for future cooperation, for example, or fear of the material and reputational costs of noncompliance.

The assumption of basic self-interested rationality also applies easily to the formation and maintenance of English property customs. Rural England was, as noted above, a place of considerable ruthlessness and social tension when it came to property acquisitions, evictions and enclosures. Market integration had also made tremendous headways by the seventeenth century, as had urbanization and non-agricultural

\footnotetext{
${ }^{99}$ See sources at supra note 17; Sugarman \& Warrington, supra note 65, at 121-35.

${ }^{100}$ For a general overview, see POMERANZ, supra note 14. On market integration in the Lower Yangtze, see LI, supra note 14. On North China, see LiLlian M. LI, Fighting FAMINE IN NoRTH ChINA 196-220 (2007). On Gansu, see Peter C. Perdue, The Qing State and the Gansu Grain Market, 1739-1864, in CHINESE History IN ECONOMIC PERSPECTIVE, supra note 14, at 100.

${ }^{101}$ See Yu Tongyuan, Ming Qing Zaoqi Gongyehua Shehui de Xingcheng yu Fazhan (The Emergence and Development of Early Industry in the Ming and Qing), 2007(11) SHIXUE YUEKAN [MONTHLY J. HIST.] 53.

${ }^{102}$ See Bell, supra note 14; discussion at infra pp. _-_.

${ }^{103}$ Intra-lineage disputes were brought to court less frequently than inter-lineage ones, see discussion at infra pp. _-_, but were nonetheless abundant. Otherwise, the intra-lineage dispute resolution mechanisms discussed at infra pp. _-_ need not have existed.

${ }^{104}$ See discussion at infra pp. _-_.
} 
production. Correspondingly, the English population arguably became more "industrious," and devoted greater attention to wealth-management. ${ }^{105}$ The problem, then, is why similarly self-interested bargaining over property norms in both China and England led to dramatically different institutional outcomes.

This article argues that the explanation lies in how the two societies allocated social status and rank. "Social status" conventionally refers to the rank of either an individual or a group in a social hierarchy of honor or prestige. ${ }^{106}$ Such hierarchies inevitably exist in human society, although they can be affected by a variety of factorsphysical prowess, wealth, religious or moral piety, age, and lineage, to name a few. Although societies vary in the relative weight they give to each specific factor, ${ }^{107}$ generally, the reputational costs of contradicting a higher status person outweigh those of contradicting a lower status one. ${ }^{108}$

This suggests a fairly straightforward model of norm negotiation: Individual property owners negotiate for property norms based on their perceived self-interest, but consider both material and reputational consequences when evaluating a particular norm. Both kinds of consequences, but particularly the latter, are influenced by the social status of allies and adversaries: all other things being equal, higher status adversaries can inflict stronger reputational damages, whereas higher status allies can convey stronger reputational rewards. Consequently, higher status individuals more often win favorable institutional outcomes.

When applied to the historical questions examined here, these deductions suggest the following: Because poorer households cumulatively possessed much higher social status in China than in England, they were able to negotiate more favorable property norms there. This incorporates large doses of self-interested rationality into the analysis: if and when richer households conceded certain property norms to poorer ones, it was not because they shared in some vaguely-defined "precommercial" ideal, but because the social cost of a prolonged standoff was too high.

The higher cumulative status of poorer Chinese households derived, as suggested above, from the "Confucian" emphasis on generational hierarchies ${ }^{109}$ : The ranking of lineage members by generational seniority - independently, in theory, of wealth — created many high-status but low-income seniors. This vastly strengthened the collective

\footnotetext{
105 See JAN DE VRIES, THE INDUSTRIOUS REVOLUTION: CONSUMER DEMAND AND THE HOUSEHOLD ECONOMY, 1650 TO THE PRESENT (2008); JOHN BROAD, TRANSFORMING ENGLISH RURAL SOCIETY: THE VERNEYS AND THE CLAYDONS, 1600-1820 (2004) (examining the rural entrepreneurship of gentry families).

${ }^{106}$ See, e.g., Yoram Weiss \& Chaim Fershtman, Social Status and Economic Performance: A Survey, 43 EURO. ECON. REV. 801, 802 (1998); Britannica Online Encyclopedia (Academic Version), Social Status, http://www.britannica.com/EBchecked/topic/551450/social-status (last visited July 1, 2012) ("Social status [is] the relative rank that an individual holds ... in a social hierarchy based upon honour or prestige").

${ }^{107}$ See Xiaotian Zhang, Status Inconsistency Revisited: An Improved Empirical Model, 24 EURO. SOCIOL. REV. 155, 156 (noting the complex factors that affect the calculation of social status).

${ }^{108}$ See Weiss \& Fershtman, supra note 106.

${ }^{109}$ But see Zhang PEIGUO, Jindai JiAngNAN XIANGCUN DiQUAN DE LiShi RENLEIXUE YANJiU [A HistoricAl ANTHROPOLOGICAL STUDY OF EARLY MODERN LAND RIGHTS IN THE LOWER YANGTZE] 27989 (2002), which attributes the advantageous social position of smallholders and tenants against oppressive landlords to intra-village "unity" against predatory outsiders. I argue below, however, that villagers argued, clashed, and negotiated amongst themselves over customary norms - and therefore that "insiders versus outsiders" thesis that Zhang suggests explains very little.
} 
bargaining power of poorer households vis-à-vis landlords and other land-accumulators, helping them win substantial concessions over property norms.

In comparison, historians generally agree that, beyond a narrow class of nobility, kinship ties were no longer of primary socioeconomic importance for most rural Englishmen by the Sixteenth Century. ${ }^{110}$ More importantly, in the resulting "individualist" social order, substantial personal wealth was almost always a prerequisite for status and authority. ${ }^{111}$ Low-income households had very little representation among the local political elite and, short of rejecting the social order itself, had limited bargaining power in property norm negotiations. They might appeal, perhaps, to social sympathy for the poor, but the strength of such sympathy was highly questionable in either country - certainly incapable of preventing widespread social tension and conflict over property norms. Consequently, English property customs gave comparatively little protection to the economic interests of small landowners and tenants.

This thesis does not assume self-interested rationality on all levels of decisionmaking, but instead recognizes that normative internalization plays an important role in distributing social status. As sociologists have long observed, norms that determine status distribution are frequently "inconsistent" with materialistic rankings of human ability, such as wealth, physical prowess, intelligence, education, or preexisting political power. ${ }^{112}$ This suggests the influence of internalized norms, often of religious or moral beliefs. Unlike tenancy or land transaction norms, people are commonly exposed to kinship hierarchies - where they exist - from childhood, often in the form of ethical exhortations, thus increasing the likelihood of widespread internalization.

Although this article takes kinship hierarchies as an independent variable, not as something to be further explained, it may be prudent to quickly outline why it assumes, as most historians have, ${ }^{113}$ that they were normatively internalized as a core moral principle by the pre-Communist Chinese population. They had simply existed for so long, and on such a massive scale, that it would be shocking if no significant internalization had taken place. Kinship hierarchies were a staple of Chinese social life since at least the wave of local lineage building around 1000 AD. ${ }^{114}$ By the Seventeenth Century, they were an indisputable cornerstone of local social organization in "core" macroregions. 115 Not coincidentally, local lineage building correlated with the rise of Song and Ming NeoConfucianism, which systematized the legal and social enforcement of kinship hierarchies with unprecedented metaphysical rigor. ${ }^{116}$ Correspondingly, one finds, in every era, an overwhelming amount of writing, including political documents,

\footnotetext{
${ }^{110}$ See sources at supra note 16.

${ }^{111}$ See sources at supra note 17.

112 See Zhang, supra note 107.

${ }^{113}$ FENG, supra note 57, at 91-168; Chang Jianhua, Jin shinian Wanqing Minguo Yilai zongzu yanjiu zongshu [Summary of the Academic Literature on Late Qing and Republican Lineages over the Past Decade], 2009(3) ANHUI SHIXUE 80.

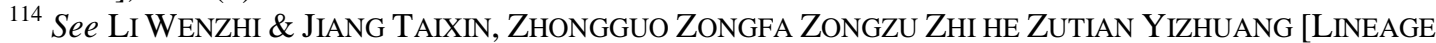
INSTITUTIONS AND COMMON PROPERTY IN CHINA] (2000); INOUE TOHRU, ZHONGGUO DE ZONGZU YU GuOJIA Lizhi [CHINA’s LineAGES AND RITUAL InstituTIONS OF THE STATE] 3-33, 227-28 (Qian Hang trans., Shanghai Bookstore Press 2008).

115 INOUE, supra note 114 , at 227-28.

${ }^{116} I d$. at $87-101$.
} 
philosophical treatises, and lineage registries, that proclaimed embeddedness within kinship hierarchies as "the natural way of heaven."117

Moral internalization coexisted, of course, with a variety of functionalist factors: With some exceptions, most Song, Ming and Qing governments promoted lineage building as a cost-effective way to establish local order and decentralize the political elite. ${ }^{118}$ Government sponsorship contributed, therefore, to the popularity of Confucian kinship hierarchies, as did the many socioeconomic functions that kinship networks performed, including dispute resolution, crime prevention, poor relief, and education. ${ }^{119}$

On the other hand, these functionalist factors cannot fully explain the consistent popularity of kinship organizations throughout a millennium of radical political and socioeconomic change: Government attitudes towards lineages were not always friendly, particularly during the Ming and mid-Qing. ${ }^{120}$ Social organization and welfare functions, on the other hand, were not the exclusive domain of kinship networks, but were also provided by religious organizations. ${ }^{121}$ There was no necessary correlation between the supply of these functions and the embracement of generational hierarchies.

In recognizing the importance of normative internalization in norm creation and maintenance, the model constructed here bears some resemblance to the "precommercial ideals" thesis. There are, however, enormous differences of degree. The model here argues for striking the right balance between normative internalization and self-interested negotiation. Property norms themselves, as demonstrated both above and below, were economically sensitive and malleable. Operating in close proximity to people's core economic interests, particularly in early modern societies, they easily inspired considerations of material self-interest and, therefore, tended to reflect equilibrium outcomes of self-interested negotiation. On the other hand, self-interested negotiation itself followed certain social rules of conduct, and could be affected particularly strongly by norms that determine status and authority distribution. The problem, then, with the "precommercial ideals" thesis is that it jumps too early into cultural internalization, leaving no room for self-interested rationality.

\section{Part Four: Empirics}

This part provides empirical support for the model put forth in Part Three, broken down into three sub-arguments: First, "dian" redemption customs were the source of widespread social tension and negotiation. They were therefore far more likely the equilibrium outcome of self-interested negotiation than the institutional manifestation of "precommercial" morality. Second, the prevalence of kinship hierarchies allowed lowerincome households to regularly occupy positions of considerable sociopolitical authority and dignity. Third, kinship hierarchies and corresponding status distribution patterns

\footnotetext{
${ }^{117}$ Numerous examples are seen in id. at 87-140, 173-202; LI \& JIANG, supra note 114, at 277-327.

118 See DAVID FAURE, EMPEROR AND ANCESTOR: STATE AND LINEAGE IN SOUTH CHINA 351-70 (2007); LI \& JIANG, supra note 114 , at 27-44, 83-84, 156-64.

${ }^{119}$ LI \& JIANG, supra note 114, at 142-50; MARY BACKUS RANKIN, ELITE ACTIVISM AND POLITICAL TRANSFORMATION IN CHINA 87-88 (1986).

${ }^{120}$ See INOUE, supra note 114, at 36-37; TONGSHI, supra note 53, at 605-14.

${ }^{121}$ See, e.g., DANIEL L. OVERMYER, FOLK BUDDHIST RELIGION: DisSENTING SECTS IN LATE TRADITIONAL CHINA 70 (1976).
} 
played a significant role in shaping the content and enforceability of "dian" redemption norms. Section Four discusses comparable patterns and trends in English sociolegal history.

\section{Section One: Conflict and Negotiation}

The clearest indication that "dian" redemption customs were never fully internalized by Qing society is the sheer volume of litigation that they caused. This is best illustrated by statistics drawn from available local case archives. Within North China and the Lower Yangtze, there are two of these, one at Baodi County, Hebei Province, the other at Longquan County, Zhejiang Province. Only the latter is well preserved enough to project a reasonably solid statistical overview. It holds 18434 cases from 1910 to 1949 , including 10614 civil suits and 7820 criminal cases. ${ }^{122}$ Accounting for the loss of case files over time, the average number of civil cases per year probably ranged from 300 to 600 - in a county of roughly 20,000 households - consistent with preexisting estimates of late Qing and Republican county-level caseloads. ${ }^{123}$ Within the 10614 civil suits, 430 stemmed from a dispute concerning "dian" sales, of which 386 focused on whether the "dian" seller should be allowed to redeem. ${ }^{124}$ Assuming a representative sample - there is no reason not to, this suggests that 4 to 5 percent of civil disputes were "dian" related, with around 85 percent of those related directly to redemption disputes. "Dian" redemption disputes were, therefore, one of the most significant sources of civil litigation. Of course, it seems unlikely that more than a fraction of contractual disputes ended up in court, which suggests that there may have been a hundred or more of these disputes in the county each year.

A more difficult question is how many "dian" redemption cases involved claims by the "dian" buyer that too much time had passed since the original contract for redemption to be allowable. Because access to the full case archive remains limited, this article relies on a randomly selected sample of sample of 80 "dian" cases, of which 65 were related specifically to "dian" redemption. ${ }^{125} 26$ of these featured express claims that the "dian" seller's redemption rights had expired after a certain period of time. ${ }^{126}$ This was the single most common rationale relied upon by "dian" buyers to reject redemption efforts.

Although precise projection is dangerous, these numbers do at least demonstrate that "dian" redemption deadlines, or the lack thereof, were in fact a frequently contested issue. Of the 26 "dian" expiration cases, 16 involved contracts that had been made more than 30 years prior to the redemption attempt, the oldest of which was made 72 years prior. ${ }^{127}$ In at least 5 of these 16, the "dian" buyer expressly cited a 1917 provincial

\footnotetext{
${ }^{122}$ Longquan Dang'an Hebian Mulu [Index of Collected Archives from Longquan] [hereinafter Longquan Index] (Dec. 5, 2011) (unpublished index, on filed with the Zhejiang University History Department).

${ }^{123}$ See Philip C.C. HuAng, Civil Justice In China: RePRESENTATION AND PRACTICE IN THE QING 164-67 (1996); MACAULEY, supra note 12, at 62.

${ }^{124}$ Longquan Index, supra note 122. Search with keywords “典,” “当,” “押,” “赎.”

${ }^{125}$ See Appendix A, Part I, in Data Appendices for "Social Hierarchies and the Formation of Customary Property Law in Pre-Industrial China and England" [hereinafter Data Appendices], http://ssrn.com/abstract=2239843 (March 26, 2013).

${ }^{126} I d$.

${ }^{127} I d$.
} 
regulation that banned redemption of "dian" contracts after 30 years. ${ }^{128}$ "Dian" sellers avoided, naturally, any mention of this regulation. It should surprise no one that the parties' normative preferences dovetailed perfectly with their perceived economic interests: "Dian" sellers preferred the customary norms of unlimited redemption, whereas "dian" buyers petitioned the court to override those norms.

The local court's response was, unsurprisingly, tepid and incoherent. In only one of the 16 cases did it enforce the 30 -year deadline against the "dian" seller. ${ }^{129}$ One other redemption attempt was rejected because the seller repeatedly failed to show in court. ${ }^{130}$ In three other cases, the court allowed redemption despite the passage of 38, 50, and 59 years. ${ }^{131}$ The remaining 11 cases were settled. Such erratic adjudicatory behavior did little damage to the reach and authority of local custom.

In addition, there is some qualitative evidence in these cases that "dian" buyers were generally far wealthier than "dian" sellers. Several "dian" sellers described their own economic circumstances as "poor," "tight," and "in shambles," while referring to the "dian" buyers as among "the wealthiest households" in the village. ${ }^{132}$ While this may simply have been rhetoric flourish, the fact that the "dian" buyers in question never contradicted these descriptions, despite their otherwise ruthless ad hominem attacks on the "dian" sellers, lends them a fair dose of credibility.

The substantive composition of "dian" disputes brought before Qing county courts elsewhere did not seem to differ significantly from the Republican-era patterns observed in Longquan. In, for example, a sample of 26 "dian"-related cases randomly drawn from the better-known Baodi, Baxian and Danxin archives-geographically covering North China, the Sichuan basin, and Taiwan, whether redemption rights expired after a certain number of years was the main point of contention in 9 cases, outnumbering all other causes of dispute. ${ }^{133}$ The time span between initial transaction and attempted redemption in these cases ranged from 11 years to 77, all beyond the 10-year deadline set by the Board of Finance. All 9 cases were eventually resolved out-of-court, generally under terms quite favorable to the "dian" seller.

A much larger spate of "dian" disputes can be found in three private case collections from the Lower Yangtze, covering the years 1875-1908. ${ }^{134}$ Combined, they yield 1063 local civil disputes, including 96 "dian"-related cases, 59 of which involved a dispute over redemption. ${ }^{135} 34$ of the 59 focused specifically on whether redemption

\footnotetext{
${ }^{128}$ Longquan Sifa Dang'an [Longquan Legal Archives] [hereinafter Longquan] M003-01-00038 (1919); Longquan M003-01-00586 (1921); Longquan M003-01-02147 (1920); Longquan M003-01-02160 (1925); Longquan M003-01-15483 (1932) (50 years).

${ }^{129}$ Longquan M003-01-02147 (1920).

${ }^{130}$ Longquan M003-01-01119 (1919).

${ }^{131}$ Longquan M003-01-00038 (1919) (59 years); Longquan M003-01-00586 (1921) (38 years); Longquan M003-01-15483 (1932) (50 years).

${ }^{132}$ E.g., Longquan M003-01-00078 (1946); Longquan M003-01-0642 (1919); Longquan M003-01-00787 (1947); Longquan M003-01-01778 (1945); Longquan M003-01-2543 (1912); Longquan M003-01-16292 (1931).

${ }^{133}$ All cases are discussed at Zhang, supra note 7, at 168-75.

${ }^{134} \mathrm{Ni}$ Wangzhong, Zhuji Yumin Jiyao, in 10 LIDAI PANLI PANDU [CASES FROM PAST ERAS] 301(Yang Yifan et al. eds., China Soc. Sci. Press, 2005); Sun Dinglie, Xisizhai Jueshi, in 10 LIDAI PANLI PANDU, supra, at 499; Zhao Youban, Liren Pandu Huiji, in 12 LIDAI PANLI PANDU, supra, at 109.

${ }^{135}$ See Appendix A, Part II, in Data Appendices, supra note 125.
} 
rights could expire. ${ }^{136}$ These ratios are similar to what we found in Baodi, Baxian, Danxin, or Longquan, clearly indicating that "dian" redemption deadlines were a significant source of social tension throughout the late Qing and Republic.

Widespread social tension over "dian" redemption deadlines also surfaces in a variety of Republican-era social surveys. The most detailed of these are Japanese surveys of rural North China conducted around 1940, otherwise known as the "Mantetsu surveys."137 Focusing primarily on six villages in Hebei and Shandong, they contain several hundred interviews with villagers on local governance, customary law, and other aspects of social organization. Naturally, general trends observed across the entire survey are more reliable than specific information drawn from individual interviewees.

One particularly striking trend is the extent to which interviewees from different economic backgrounds quarreled over property norms. In the two most extensively surveyed villages, Sibeichai and Shajing, researchers asked over twenty villagers about what they thought were the customs that governed "dian" transactions. ${ }^{138}$ In Sibeichai, all interviewees agreed that "dian" redemption had no deadline, ${ }^{139}$ but at least one local landlord complained that it was an "archaic" custom. ${ }^{140}$ On several other issues, the landlords clashed openly with poorer village leaders over what the customs really were: One former village chief of middling wealth argued that "dian" sales could be redeemed even before the "guaranteed usage period" had expired, and even if the "dian" seller owed additional debt to the "dian" buyer. ${ }^{141}$ Several others concurred. ${ }^{142}$ Landlords and wealthier farmers disagreed: "Dian" buyers could deny redemption if the "dian" seller owed any outstanding debt, or if the guaranteed usage period had yet to expire. ${ }^{143}$

In Shajing, social discord existed not only over these comparatively minor issues, but also over whether "dian" redemption rights truly were interminable. Most interviewees stated that local custom allowed redemption regardless of time passage since the initial contract, ${ }^{144}$ but one person, unsurprisingly one of the largest landowners in the village, declared that the true governing principle was the thirty-year redemption deadline enacted by the 1929 Republican Civil Code. ${ }^{145}$ According to a poorer interviewee, however, the rule was generally unenforceable in practice. ${ }^{146}$

Three other villages, Lengshuizhuang, Houxiazhai, and Wudian, resembled Sibeichai more than Shajing, in that all interviewees affirmed the basic principle of interminable redemption rights, but argued vigorously over more technical rules - for example, whether guaranteed usage periods were enforceable. ${ }^{147}$ At Houjiaying,

${ }^{136} I d$.

${ }^{137}$ MANTETSU SURVEYS, supra note 86, vols. 1-5.

${ }^{138}$ Shajing is covered in 1\&2 MANTETSU SURVEYS, supra note 86. Sibeichai is covered in 3 MANTETSU

SURVEYS, supra note 86.

1393 MANTETSU SURVEYS, supra note 86, at 166,172, 176, 246, 273.

${ }^{140} \mathrm{Id}$. at 174 .

${ }^{141} I d$. at $170-71,273,275$.

${ }^{142} I d$. at $245,263$.

${ }^{143}$ Id. at $165-67,173-174,247-48$.

1442 MANTETSU SURVEYS, supra note 86, at 174, 187, 269.

145 Id. at 169.

${ }^{146}$ Id. at 269.

${ }^{147}$ For Lengshuizhuang, see 4 MANTETSU SURVEYS, supra note 86, at 205-06, 214, 222-24, 257. For Houxiazhai, see 4 MANTETSU SURVEYS, supra note 86, at 482-85, 508-11. For Wudian, see 5 MANTETSU SURVEYS, supra note 86 , at 531, 562-63, 578, 583-84. 
however, one interviewee declared that "although the traditional rule was that redemption could take place at any time, now it must be done within thirty years." "148 This was a once-wealthy store owner who possessed some real estate that his deceased brother had "dian" purchased years ago from poorer neighbors, relying upon it to maintain a decent standard-of-living. ${ }^{149}$ It is hardly surprising, then, that he both knew of the thirty-year redemption law and attempted to take advantage. Other interviewees who were, in fact, "dian" sellers disagreed in strong terms. ${ }^{150}$

The picture that emerges from this array of sources, both cases and interviews, is one of tension and dispute over customary norms, but not of social chaos in which no operative norm existed. Despite the large array of cases that involved the "dian" buyer arguing that redemption rights expired after either ten or thirty years, an equally eyecatching trend is that, when the great majority of these cases were resolved out-of-court, these same people almost always agreed to terms quite favorable to the "dian" seller, at least in cases that report the settlement terms. Most often, after further negotiation between senior relatives from both sides, they would simply allow the "dian" seller to redeem. ${ }^{151}$ In the other cases, they retained possession of the land, but only after giving the seller an additional payment, and often without receiving any promise that redemption was henceforth prohibited. ${ }^{152}$ This casts into doubt the strength of their resolve against these "archaic" customs. Their behavior is that of a practical "forum shopper" who attempts to take advantage of the more accommodating property norms provided by the central government, but retreats once the odds worsen and social pressure intensifies. The resigned complaints of the frustrated Sibeichai landlord provide further support for this interpretation. ${ }^{153}$ Even in Shajing and Houjiaying, the few interviewees who proposed overriding traditional custom with legal regulations nonetheless recognized that those customs did provide for unlimited "dian" redemption. ${ }^{154}$

There is, therefore, strong historical evidence that local communities regulated "dian" transactions via customary law, but also that these customs were the source of much social contention. In all likelihood, they were created via negotiation between selfinterested and, insofar as their preferred norms correlated to their perceived economic self-interest, basically rational parties. Strikingly, the wealthiest segments of rural communities frequently felt powerless against their poorer neighbors, and had to tolerate property norms that substantially damaged their socioeconomic interests.

\section{Section Two: Patterns of Status Distribution}

This section measures the relative effects of kinship and wealth on status distribution. It turns first to the Mantetsu surveys, which yield detailed demographic and landholding data for all surveyed villages. The interviews identify 126 political elites

\footnotetext{
148 MANTETSU SURVEYS, supra note 86, at 286.

${ }^{149}$ Id. at $284-85$.

${ }^{150} \mathrm{Id}$. at 266.

${ }^{151}$ See Zhang, supra note 7, at 172-75; Longquan M003-01-00642 (1919); Longquan M003-01-00787

(1947); Longquan M003-01-01166 (1920); Longquan M003-01-11063 (1922); Longquan M003-01-15821 (1943).

${ }^{152}$ E.g., Longquan M003-01-01283 (1923); Longquan M003-01-05358 (1948).

${ }^{153}$ See discussion at supra note 140.

1542 MANTETSU SURVEYS, supra note 86, at 174; 5 MANTETSU SURVEYS, supra note 86, at 286.
} 
across seven villages, current and former, who can be matched with landownership and kinship information. ${ }^{155}$ These included village chiefs and their deputies, major lineage chiefs, and "jiazhang" ("ten-household chiefs") or equivalent. Not included in this sample are people whose landholding information is unavailable.

Quite contrary to what previous - and far less statistically thorough — studies of the Mantetsu surveys have suggested, lower-income households were proportionally represented among the village political elite. 63 of the 128 owned less land than the village median. ${ }^{156}$ Nor were all 63 concentrated in "lower-tier" positions - "jiazhang" (head of a village subdivision) rather than village chief, for example. Of the 32 people identified to have been village chief during the past decade, 14 owned less land per-capita than the village average. ${ }^{157}$ Of the 35 largest landowners from the seven villages, only 9 had wielded any formal political authority in recent years. ${ }^{158}$ This was, of course, still a considerably higher ratio than among lower-income households, but nonetheless low enough to suggest that landed wealth was a weak determinant of sociopolitical authority.

On the other hand, the correlation between sociopolitical authority and generational seniority was extremely strong. At least 108 of the 128 individuals belonged to the most senior generation of what villagers identified as a "major kinship group." 159 Only 9 people clearly belonged to a younger generation, whereas the generational standing of the other 11 are unclear. ${ }^{160}$ This suggests that well over 90 percent of village political elites belonged to the senior generation of a major kinship group.

The above analysis assumes that political leadership positions were generally objects of social desire, and therefore fairly accurate proxies for high status and authority. But was this true? Based also on the Mantetsu surveys, Prasenjit Duara has argued that the richest North China households actually avoided assuming direct political authority, considering it burdensome and risky. ${ }^{161}$ The sole piece of evidence for these claims is an interview with Du Fengshan, a Lengshuizhuang village chief who had served for over two decades despite owning almost no land. Du notes that the village had undergone a political reorganization after 1935, in which 14 lüzhang (a jiazhang equivalent) replaced the 8 shoushi ("chief administrators") who had previously handled basic administration. He then lists from memory the names and landholdings of all 22 men. ${ }^{162}$ There was, as Duara points out, no overlap between the two administrations. Moreover, Du reports notably higher landholding figures for the 8 shoushi than for the 14 lüzhang. Duara argues, therefore, that the village economic elite, as represented by the 8 shoushi, had consciously withdrawn from political leadership positions. ${ }^{163}$

However, Du's recollection is extraordinarily unreliable: no other interviewee ever mentions the 8 shoushi he lists, and only one of them can be found on the village

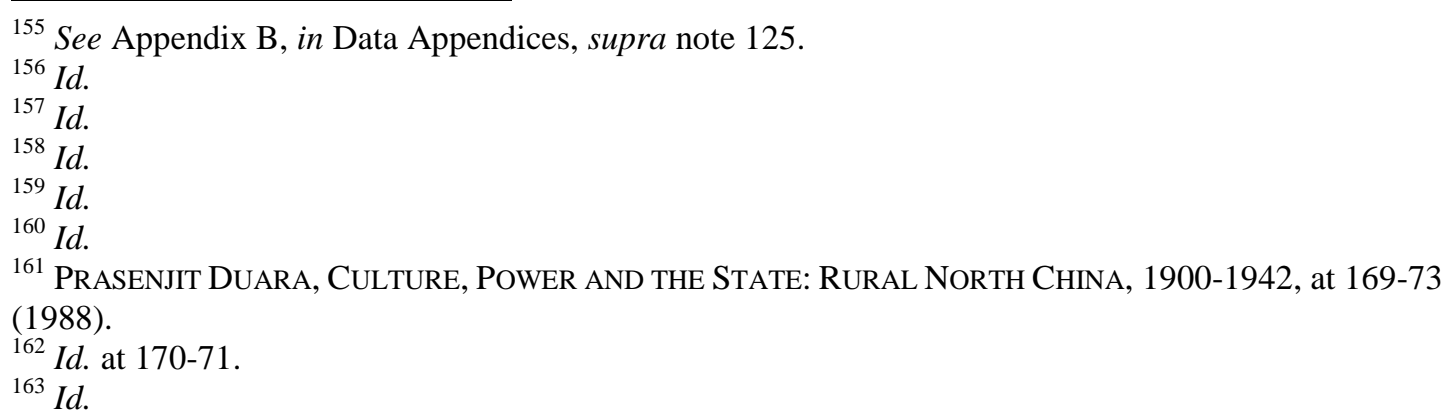


land registry. ${ }^{164}$ Moreover, that one person actually owned only $2 \mathrm{mu}$, not the $20 \mathrm{mu}$ that Du reported. ${ }^{165}$ Du's list of the 14 lüzhang was likewise inaccurate. He misstates the names of 4 people, and provides wildly inaccurate landholding numbers for another $5 .{ }^{166}$ Whether Du was consciously misleading the Japanese researchers is unclear-his advanced age may have impaired his memory. Moreover, although there was no overlap between the 14 lüzhang and the 8 shoushi that immediately preceded them, one lüzhang had, in fact, been part of an earlier class of shoushi. ${ }^{167}$ The two classes of shoushi also shared only one common member, suggesting that the large volume of personnel turnover was traditionally normal. There is simply no reliable evidence that Lengshuizhuang economic elites "withdrew" from village politics. Quite the opposite, some had considerable political aspirations, even in 1940: According to one interviewee, the village's largest landowner could not obtain his desired sociopolitical status "because he [was] only in his twenties."168

The conclusions drawn here stand in distinct opposition to two previous studies of the Mantetsu surveys: Duara's, of course, but also Philip Huang's important study of the North China economy. Both suggest that, quoting Huang, "lineage leaders and village 'councilmen' were generally also the village rich."169 They rely, however, on highly incomplete surveys of village elite: Huang relies on a sample of 18 people; ${ }^{170}$ while Duara provides only incomplete lists from Shajing, Houjiaying, and Lengshuizhuang. ${ }^{171}$ More comprehensive coverage demonstrates, however, that lower-income households were hardly underrepresented among the political elite.

Certain regions of North China were, of course, more economically stratified than others. Joseph Esherick and Kenneth Pomeranz have noted, for example, that resident landlordism was more prevalent in the southwestern edge of Shandong Province than in other regions of North China, with large landlords owning perhaps a third or more of all arable land. ${ }^{172}$ Whether this meant that they dominated local social and political authority, however, is ambiguous. The main sociopolitical function they controlled were organizing and funding local militias — something only the rich could provide. ${ }^{173}$ Otherwise, there is no clear evidence that the ranks of local political elite were forcibly monopolized by higher-income households. Southwestern Shandong villages were highly consolidated, demographically stable, and resistant to government intervention, ${ }^{174}$ but this suggests cooperation between rich and poor as much as stratified dominance.

Social organization in the Lower Yangtze was different in several aspects, but nonetheless similar in that it revolved around large kinship networks. Unlike North China kinship groups, which owned almost no common property, a small but notable fraction of arable land in the Lower Yangtze was owned not by individual households,

\footnotetext{
${ }^{164}$ See 4 MANTETSU SURVEYS, supra note 86, at 1-29, 386-89.

${ }^{165} \mathrm{Li}$ Fenggui. Id. at 387.

${ }^{166}$ Compare id. at 25 , and id. at 386-89.

${ }^{167} \mathrm{Id}$. at 25

${ }^{168}$ Id. at 8 .

${ }^{169}$ HUANG, supra note 31, at 238.

${ }^{170} I d$. at $238-39$.

${ }^{171}$ DUARA, supra note 161 , at 162, 166, 171 .

172 JOSEPH ESHERICK, ORIGINS OF THE BOXER UPRISING 1-37 (1988); POMERANZ, supra note 31, at 101-04.

${ }^{173}$ ESHERICK, supra note 172, at 23.

${ }^{174} I d$. at $12-13,23-27$.
} 
but by lineages ("zongzu") — commonly understood as kinship groups that collectively owned some property, under arrangements quite similar to modern corporate holdings. ${ }^{175}$ Compared to North China kinship groups, these lineages were better organized and more populous. ${ }^{176}$ Whereas the average North China village might possess several kinship groups, each consisting of a few dozen households, Lower Yangtze villages were very often dominated by one large lineage, operating under published regulations and detailed conduct codes. Political authority and status in geographical communities were therefore inseparable from authority and status within lineages. But how did lineages allocate status?

We focus here on the considerable number of lineage registries that were produced throughout the Qing and early Republic. Apart from recording the family tree, they also contained significant information on the use and maintenance of common property, rules of personal conduct, and rules on the selection of lineage heads and councilors. The collection of twelve registries analyzed here all hail from the Ningbo, Shicang and Longquan regions of Zhejiang Province, each correlating to a large lineage that dominated at least one village between 1870 and $1930 .{ }^{177}$

These lineages shared two basic organizational characteristics. First, none of the registries positively identify personal wealth with higher internal status and authority. At least three, in fact, expressly condemned as immoral the allocation of status based on material affluence. The natural order of families was, they stated, one that gave senior members precedence over junior ones, and any corruption of this principle by materialistic concerns was intolerable. ${ }^{178}$ Second, of the seven lineages that published selection criteria for leadership positions, all seven highlight the importance of

\footnotetext{
${ }^{175}$ See Teemu Ruskola, Conceptualizing Corporations and Kinship: Comparative Law and Development Theory in a Chinese Perspective, 52 STAN. L. REV. 1599, 1614 at n.37 (2000).

${ }^{176}$ See Kung-Chuan HSiaO, Rural China: Imperial Control in the Nineteenth Century 326 (1960); Philip C.C. Huang, The PeASAnt Family and RuRal DeVelopment In the Yangzi Delta, 1350-1988, at 144-48 (1990); LI \& JIANG, supra note 114, at 167-77. See, however, Kathryn Bernhardt's characterization of Lower Yangtze lineages as "based in urban centers" and loosely organized in rural areas. BERNHARDT, supra note 21, at 19-21. More recent scholarship suggests that Bernhardt significantly underestimates the social importance of rural lineage groups. See Zhang Jinjun, Qingdai Jiangnan Zongzu zai Xiangcun Shehui Kongzhi zhong de Zuoyong [The Role of Lineages in the Qing Lower Yangtze], 34(3) J. ANHUI NORMAL. UNIV. 353 (2006).

${ }^{177}$ Eight of these are held at the Shanghai Library: NANJIN JIANGSHI MinfANG FAXIANG PU [REGISTRY OF THE Min BRANCH OF THE NINGBO JIANG LINEAGE] (1890); JIANGSHI ZHIPU [BRANCH REGISTRY OF THE JiANG LinEAGE] (Yu Zhonghuan ed.,1934); SiMING ZHUSHI ZHIPU [BRANCH REGISTRY OF THE ZHU LiNEAGE OF SimING] (Zhu Xiang ed., 1936); XUdETANG YinJIA PU [REGISTRY OF THE Yin LiNEAGE OF XudETANG] (1906); YongShang Tushi ZONGPU [REGISTRY OF THE TU LINEAGE OF YongShANG] (Zhang Meisa ed., 1919); BIANSHI ZONGPU [REGISTRY OF THE BIAN LINEAGE] (Bian Yingshan et al. eds., 1874); YAONAN DINGSHAN FANGSHI ZONGPU [REGISTRY OF THE FANG LINEAGE FROM DINGSHAN, IN YAONAN] (Fang Zheng et al. eds., 1921); Dushi ZONGPU [REGISTRY OF THE DU LiNEAGE] (Du Xizhen ed., 1948). Three, from Longquan County, are held at the Zhejiang University History Department: NANYANG YESHI ZONGPU [REGISTRY OF THE YE LINEAGE OF NANYANG] (Ye Liming et al. eds., 1998); XUSHI ZONGPU [REGISTRY OF THE XU LINEAGE] (Zu Fenglu ed., 1937); GUANCHUAN MAOSHI ZUPU [REGISTRY OF THE MAO LINEAGE OF GUANCHUAN] (late Qing, year unknown). One, from Shicang village, is held at the Shanghai Jiaotong University History Department: QUESHI ZONGPU [REGISTRY OF THE QUE LINEAGE] (Hu Ruixiang ed., 1896).

${ }^{178}$ JIANGSHI ZHIPU, supra note 177; DUSHI ZONGPU, supra note 177; QUESHI ZONGPU, supra note 177.
} 
generational seniority. ${ }^{179}$ The Jiang lineage of Ningbo, for example, divided its members into five subgroups, each of which sent the eldest member of the highest generation to the lineage council. ${ }^{180}$ This five-person council arbitrated all internal disputes, represented the lineage in external negotiations, managed common property, coordinated labor and resource sharing, and enforced lineage regulations. In this latter task, the council could often count on the county government's backing, to the point where "bringing offenders to the county court" was listed as the punishment of last resort. ${ }^{181}$

Among members of the same generation, one lineage in our sample chose to rank individuals not by age, but by lineal proximity to a descent line of firstborn males extending back to the founding ancestor: his eldest son, the eldest son's eldest son, and so on. ${ }^{182}$ This line of eldest sons ("zongzi") enjoyed higher status than other members of their generation, regardless of age. All other members were ranked by their lineal proximity to him: his brothers would, for example, have social precedence over his cousins, usually through more prominent roles in ancestor worship rituals and easier access to lineage leadership positions. In some lineages, although none in our sample, the "zongzi" could succeed his father as lineage head even if some of the father's generation still lived, although in such cases he shared authority with councilors from the higher generation. ${ }^{183}$ For the purposes of this article, these systems are not fundamentally different from straightforward ranking by seniority, in that they rank lineage members according to criteria that have little discernible correlation to wealth. Previous scholarship on Lower Yangtze lineages suggest, in any case, that straightforward ranking by generation and age gradually replaced "zongzi" systems during the Ming and Qing. ${ }^{184}$ Intelligence and possession of official degrees - extremely rare in the Qing ${ }^{185}$ - were also important considerations, but wealth per se did not obviously matter. ${ }^{186}$

Lower Yangtze lineages were, in this regard, noticeably different from lineages in South China. In Fujian Province, scholars have identified three major structural categories: "inheritance lineages," which, like the Lower Yangtze lineages described above, assigned leadership positions strictly based on generational seniority; "controlsubordination" lineages, where wealthier households expressly dominated poorer ones; and "contractual lineages," usually creations of convenience where various non-related households banded together due to shared economic interests, and where leadership selection was less organized. ${ }^{187}$ "Inheritance lineages" were still predominant in the late-

\footnotetext{
179 JIANGSHI ZHIPU, supra note 177; SIMING ZHUSHI ZHIPU, supra note 177; YONGSHANG TUSHI ZONGPU, supra note 177; BIANSHI ZONGPU, supra note 177; YAONAN DINGSHAN FANGSHI ZONGPU, supra note 177; DUSHI ZONGPU, supra note 177; QUESHI ZONGPU, supra note 177.

${ }^{180}$ JIANGSHI ZHIPU, supra note 177.

${ }^{181} I d$.

${ }^{182}$ NANJIN JIANGSHI MiNFANG FAXIANG PU, supra note 177.

${ }^{183}$ FENG ERKANG, 18 SHIJI YILAI ZHONGGUO JIAZU DE XIANDAI ZHUANXIANG [THE MODERN TURN OF CHINESE LINEAGES SINCE THE $18^{\mathrm{TH}}$ CENTURY] 108-11 (2005).

${ }^{184}$ Id. at 95-96, 111-13, 248-56.

${ }^{185}$ See discussion at supra p._.

${ }^{186}$ Feng, supra note 183 , at 111-13; Zhang, supra note 176, at 354-56.

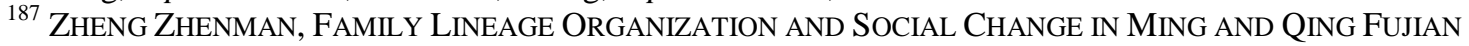
71-142 (Michael Szonyi trans., Univ. of Hawai'i Press 2000). Other major Western studies of South China lineages include FAURE, supra note 118; MiCHAEL SZONYI, PRACTICING KINSHIP: LINEAGE AND DESCENT IN LATE IMPERIAL CHINA (2002); MAURICE FREEDMAN, CHINESE LINEAGE AND SOCIETY: FuKIEN AND KWANGTUNG (1966).
} 
Qing, ${ }^{188}$ but as corporate landholding expanded, the need for efficient management occasionally concentrated authority into the hands of the most economically capableusually the wealthiest—households, creating a "control-subordination" lineage. ${ }^{189}$

The major difference between South China and the Lower Yangtze was, however, precisely the amount of corporate land owned by lineages. Previous estimates of lineage property show that, apart from South China, where it exceeded 35 percent of total arable land, lineage landholding was trivial elsewhere. ${ }^{190}$ The economic rationales and conditions that sometimes transformed "inheritance lineages" into less egalitarian forms were therefore abundant in South China, but largely absent in the Lower Yangtze.

The existence of "control-subordination" and "contractual" lineages in South China demonstrates that normative appeal of Confucian kinship ideals was not immune from erosion by economic factors. It does not, however, imply that such ideals were in widespread jeopardy. It would otherwise be difficult to explain the predominance, in both North China and the Lower Yangtze, of kinship groups that adhered closely to them, or even the smaller majority of "inheritance lineages" in South China.

\section{Section Three: Kinship Hierarchies and Property Norms}

The previous two sections have demonstrated that "dian" customs were the product of self-interested negotiation, and that local status distribution correlated far better with "Confucian" kinship hierarchies than with wealth distribution. It remains to show to show that the relatively egalitarian distribution of status and rank facilitated by these kinship hierarchies affected norm negotiation and enforcement in ways that favored seller-friendly "dian" customs.

This is relatively straightforward for North China, where the Mantetsu surveys provide numerous insights on the roles of village political elites in norm negotiation. First and foremost, village leaders of middling or lower wealth were often quite aggressive in protecting these customs against attempted erosion by landlords. The clearest example of this is when Zhang Leqing, former village chief of Sibeichai and middling landowner, engaged in a prolonged battle with local landlord Lin Fengxi over the proper procedure for "dian" redemption. ${ }^{191}$ Zhang argued, internally and to county investigators, that his redemption of a "dian" sale from Lin was only dependent upon repayment of the initial "dian" price. ${ }^{192}$ He had later accrued additional debt to Lin, but that was unrelated and immaterial. Lin countered that, because he had allowed Zhang to remain on the "dian"-sold property as a rent-paying tenant, and because the additional debt was actually several years of unpaid rent, it was too closely tied to the initial "dian" transaction for Zhang to redeem without full repayment of all outstanding rent. ${ }^{193}$ This was, to Lin, what local custom "should" have been.

Several local landlords voiced their support for Lin, ${ }^{194}$ but other lower-income village elites sided with Zhang. ${ }^{195}$ By the time of the interview, the dispute was still

\footnotetext{
${ }^{188}$ ZHENG, supra note 187 , at 186.

${ }^{189} \mathrm{Id}$.

${ }^{190}$ Pomeranz, supra note 14, at 71-72; CHEN HAN-SENG, LANDLORD AND PEASANT IN CHINA 34-35 (1936).

1913 MANTETSU SURVEYS, supra note 86, at 170-71, 273-75.

${ }^{192} I d$.

${ }^{193} I d$. at $171-174$.

${ }^{194}$ Id. at $165-67,177-86,247-48$.
} 
ongoing, but Zhang was confident that his view would prevail. ${ }^{196}$ Lin, meanwhile, seemed resigned that he would be unable to recuperate the outstanding rent before Zhang redeemed, complaining that he could not fight the "stubborn" villagers who stuck to their "backwards customs."197

Although most disputes over "dian" customs in the surveyed villages were relatively narrow and technical, similar to the Zhang Leqing-Lin Fengxi dispute, they could sometimes trigger broader debates among village leaders about the expiration of "dian" redemption rights. As discussed above, a few wealthy interviewees suggested superseding traditional customs with national regulations that banned redemption after thirty years. ${ }^{198}$ Naturally, lower-income interviewees rejected this out-of-hand. ${ }^{199}$

Many of these lower-income individuals were, in fact, members of the village political elite. For example, Li Liangfu, a Lengshuizhuang village official of middling wealth, seemed to know of the thirty-year legal deadline, but rejected outright any notion that it should be enforceable in his village. Similar statements were made by Zhao Shaoting, village councilor of Shajing, Hou Dingyi, former village chief of Houjiaying,

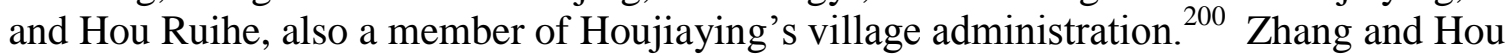
Ruihe were both below-average landholders, whereas Hou Dingyi was slightly aboveaverage in terms of overall household landholding, but probably below average on a percapita basis due to the unusually large size of his household. ${ }^{201}$ In the three other surveyed villages, the thirty-year redemption deadline was never openly discussed, but researchers nonetheless encountered middling or low-income village leaders who expressed preferences for "dian" customs that would allow "dian" sellers to, for example, redeem even before the guaranteed-usage period had expired, or reject any right-of-firstpurchase claim made by "dian" buyers. ${ }^{202}$

Another notable observation is that the only two villages, Shajing and Houjiaying, ${ }^{203}$ where some interviewees expressly argued-if unsuccessfully-that "dian" redemption rights should expire beyond a certain deadline also happened to be the only two villages where large landlords appeared to enjoy some noticeable political advantage $^{204}$ : In Shajing, 5 of the top 8 village leaders ("huishou"), including the only identifiable village chief, owned significantly more land per-capita than the village average. In fact, 4 of them, including the village chief, owned more than twice as much. In Houjiaying, 8 of 10 identifiable current and former village chiefs were above average landholders, including 5 people who owned at least three times the average amount, 2 of whom were among the village's top 5 landholders. Additionally, 3 of 5 identifiable vice village chiefs were above-average landholders. In no other surveyed village do aboveaverage landholders account for more than half of identifiable village chiefs, vice-village

\footnotetext{
${ }^{195} I d$. at $245,263$.

${ }^{196} \mathrm{Id}$. at $170-71$.

${ }^{197}$ Id. at 174 .

${ }^{198}$ See discussion at supra $\mathrm{p}$._.

${ }^{199} \mathrm{Id}$.

${ }^{200}$ See supra notes $146,150$.

${ }^{201}$ See Appendix B, in Data Appendices, supra note 125.

${ }^{202}$ See supra notes 144-150. Specific examples include Du Fengshan in Lengshuizhuang, Ma Wannian in Houxiazhai, and Zhao Xianzhang in Wudian.

${ }^{203}$ See discussion at supra $\mathrm{p}$._.

${ }^{204}$ See Appendix B, in Data Appendices, supra note 125.
} 
chiefs, or "huishou"/"baozhang"-level ${ }^{205}$ officials. Of course, even in Shajing and Houjiaying, lower-income households still occupied most of the lower-ranked political positions, but larger landholders did seem to enjoy a substantial edge in obtaining the top positions. While this may be pure coincidence - that possibility is hard to rule out in a sample of only seven villages - one reasonable interpretation is that the customary right of unlimited "dian" redemption was more secure in villages where large landholders were politically weaker.

All this suggests, ultimately, that vigorous support from lower-income political elites was quite instrumental in sustaining and enforcing seller-friendly "dian" norms. Their support could take effect in a variety of ways: As many interviewees attested, village officials usually played crucial roles in mediating and settling "dian" and permanent sale related disputes, and therefore had numerous opportunities in everyday economic life to encourage and perhaps enforce adherence to their preferred institutional norms. ${ }^{206}$ The Zhang Leqing-Lin Fengxi dispute also highlights the somewhat higherlevel forums, including formal litigation and village-wide "policy" debates, in which advocacy and support by sympathetic political elites could be particularly effective at reinforcing customary property institutions.

The Lower Yangtze poses greater empirical challenges. There are few sources there, if any, that directly document the positions of village or lineage elites in "dian"related disputes - certainly nothing comparable to the Mantetsu surveys. Fortunately, there is much circumstantial evidence to be found, from both the county case archives discussed above and several major collections of land contracts from the same periods.

Whether in North China or the Lower Yangtze, few potential "dian" buyers and sellers negotiated contracts themselves. Rather, one side would typically ask a middleman to contact the other side, gather both sides' preferences, propose a reasonable compromise, measure the land, and, finally, draw up the deed. If any disputes flared up after the contract signing, the middleman would likewise supervise initial mediation and renegotiation attempts. ${ }^{207}$ Given these expansive duties, he needed to command enough trust and respect within the community to effectively broker deals and settle disputes.

The argument here is that the great majority of Lower Yangtze middlemen were relatively senior members of either the "dian" seller's or the "dian" buyer's kinship group. These were usually identical, as most people preferred to do business with relatives. In any case, the near-omnipresence of senior kinsmen in "dian" sales strongly suggests that kinship groups were heavily involved with the negotiation and enforcement of proper behavior in these transactions.

These claims rely on data culled from two recently discovered contract collections in Zhejiang. The first is a set of 415 late-Qing land contracts from the Ningbo region, of which 412 were "dian" sales contracts, redemption contracts, or conversions from "dian" to permanent conveyance. ${ }^{208}$ All 415 identify not only the names of middlemen, but also their kinship affinity, if any, with either contracting party-usually the seller. 403

\footnotetext{
${ }^{205}$ Generally the highest rank behind village chief and vice-village chief.

${ }^{206}$ E.g., 3 MANTETSU SURVEYS, supra note 86, at 29;4 MANTETSU SURVEYS, supra note 86, at 7, 206-07, 406-07; 5 MANTETSU SURVEYS, supra note 86, at 5-6; 439.

${ }^{207}$ See HuANG, supra note 123, at 52-58; HUAIYIN LI, Village GOVERNANCE IN NORTH CHINA, 1875-1936, at 54-55 (2005).

${ }^{208}$ NingBO CONTRACTS, supra note 87. The three exceptions are id., at nn. 81, 167, 169.
} 
contracts employed at least one elder relative as middleman. ${ }^{209}$ Moreover, of the 389 transactions made between members of the same lineage, 385 employed only fellow lineage members as middlemen. ${ }^{210}$ The most sought-after middlemen were generally senior members of one's lineage, ${ }^{211}$ brokering contracts for nephews or junior cousins. There is no indication that personal wealth enhanced one's perceived fitness to be middleman - many, even the most popular, were themselves indebted "dian" sellers. ${ }^{212}$

The second contract collection is a batch of 140 land sales from Shicang Village, Songyang County, spanning the years 1865 to $1915 .^{213} 108$ of these, or 77 percent, were "dian" transactions. The social composition of middlemen in these contracts was almost identical to the Ningbo collection: 130 of the 140 land sales, and 103 of 108 "dian" transactions, involved at least one middleman who was an elder relative of one contracting party, and the great majority involved at least three. ${ }^{214}$ Here, too, certain senior members of the locally dominant lineage were in high demand. ${ }^{215}$

These empirical patterns highlight the influence that senior lineage members exerted on land transactions and their underlying social norms. Most importantly, middlemen were also mediators and arbitrators of first-resort in case of dispute, and therefore exercised considerable authority over the contracting parties. Employing senior relatives as middlemen further strengthened such authority and gave them a legitimate opportunity to advocate and enforce their understanding of local property norms. From there, it is but a small step to suggest that, because these senior relatives were often themselves low-income "dian" sellers, their wide-ranging influence over transactions weakened the ability of higher-income households to obtain their preferred normative and contractual outcomes.

One would also expect that this weakening effect was particularly strong in intralineage "dian" sales, as the influence of middlemen should have been significantly stronger when they were related to both parties. On the other hand, middlemen who were unrelated to either side possessed comparatively less authority, as the reputational costs of ignoring or contradicting them were significantly lower. This increased the potential for extended conflict and ruthless bargaining tactics in inter-lineage transactions. For example, inter-lineage sales accounted for a strong majority of "dian" disputes in the Lower Yangtze county cases discussed in Section One, ${ }^{216}$ even though they probably accounted for only a small fraction of all "dian" sales. ${ }^{217}$ Therefore, if kinship hierarchies affected the negotiation and enforcement of "dian" customs in favor of lower-income households, their effect should have been greater in cases where buyer and seller belonged to the same lineage.

This is precisely what we find in these county-level cases. ${ }^{218}$ In one 1896 case from Zhuji County, a relatively junior member of the local Zhou lineage attempted to ban

\footnotetext{
${ }^{209}$ Exceptions are id., at nn. 207, 208, 227, 228, 230, 231, 233, 272, 367, 395, 401, 411.

${ }^{210}$ Exceptions are id., at nn. 333, 338, 392, 411.

${ }^{211}$ Examples include Mao Rongkun, Mao Renli, Mao Youpei and Mao Shengen. E.g., id., at 8, 23, $27,9.8$.

${ }^{212}$ E.g., id., at 82, 87 (showing “dian” selling by Mao Youpei and Mao Rongkun).

213 SHICANG CONTRACTS, supra note 87.

${ }^{214}$ Exceptions include id., at 15, 16, 73, 107, 131, 133, 147, 167, 168, 209.

${ }^{215}$ Examples include Que Hansheng and Que Hanliu. E.g., id., at 8, 9.

${ }^{216}$ See Appendix A, Part II, in Data Appendices, supra note 125.

${ }^{217}$ See discussion surrounding supra note 210.

${ }^{218}$ Lidai Panli Pandu vol. 10, at 403-04, 443, 449, 484; vol. 12, at 303, 397.
} 
a cousin-in-law from redeeming land her husband had conveyed to him five years ago. ${ }^{219}$ The point of contention was whether the conveyance was a "dian" sale-here termed a "ya" transaction - or a permanent one. After consulting with other community members, the magistrate decided that the debate was immaterial: "[A]t the time of the transaction, the parties clearly should have understood that, because they were relatives, not only was a "dian" sale certainly redeemable, but there was also no reason why a permanent sale would not be. ... In any case, [the defendant] is [the plaintiff's] senior cousin-in-law ...., so why does he not treat her according to reason and moral responsibility?"220 This was no isolated incident: similar decisions appear in at least three other cases. ${ }^{221}$

The magistrate cites no clear authority for this extraordinary claim, but unless we assume incredible ignorance of central laws and regulations, he was probably aware that it violated every formal legal authority possible. ${ }^{222}$ Moreover, it seems implausible that he believed that this was some universal moral commandment - the steps he took to reach the conclusion, including meeting with community members, indicate that he was persuaded of its applicability under certain circumstances, not that he came in with apriori moral faith in it. This strongly suggests that the claim derived from his understanding of local customary practices.

He was not alone in this observation. It also appears in three cases decided by another Lower Yangtze magistrate from the same era, who commented that, because "dian" buyers were expected to show greater leniency for low-income kinsmen, permanent sales between kinsmen were redeemable. 223 The vast majority of "dian" sellers would probably have appreciated this extra concession, especially if, as argued above, the selling of property was usually a last resort in times of extraordinary financial need. All this suggests, as argued above, that middlemen were often sympathetic towards the economic interests of lower-income relatives, and could act upon that sympathy more strongly in cases where the transacting parties were kinsmen.

\section{Section Four: English Comparisons}

Ultimately, there is much evidence, from both North China and the Lower Yangtze, that the relatively egalitarian status-distribution patterns within kinship hierarchies affected norm negotiation and enforcement in ways that promoted sellerfriendly "dian" customs. But does the prevalence of kinship hierarchies in China - and the lack thereof in England-also explain the institutional divergence between Chinese and English property customs? This article argues, of course, that they do. This again relies on three sub-arguments: First, English property norms, like Chinese ones, were largely the product of self-interested maneuvering and negotiation. Their comparatively weaker protection of lower-income households reflected, therefore, the weaker bargaining position of those households. Second, substantial landed wealth was generally a prerequisite for high social status and political leadership in rural England, allowing large landowners to monopolize positions of power. Third, kinship networks were far less expansive and influential in England than in China and, consequently, were

21910 LIDAI PANLI PANDU, supra note 134, at 443.

${ }^{220} \mathrm{Id}$.

${ }^{221} I d$. at 403-04, 449, 484.

${ }^{222}$ See DQLL, supra note 73, at $\S$ 95-03, 95-07.

${ }^{223} 12$ LIDAI PANLI PANDU, supra note 134, at 303, 397. There are two cases on page 397. 
of marginal significance in status distribution and norm negotiation. Ultimately, the reach and influence of "Confucian" kinship hierarchies in China was indeed a distinct factor that substantially explains the Sino-English divergence in property regulation.

Preexisting scholarship provides largely consensual support for all three subarguments. As discussed above, studies of early modern English land norms have highlighted the aggressive, even ruthless, manner in which large landlords attempted to reshape property norms in their favor. ${ }^{224}$ Especially in the $16^{\text {th }}$ and $17^{\text {th }}$ Centuries, the wide array of unilateral enclosures, evictions, rent and fee manipulation, and default seizures that wealthy households employed to accumulate and consolidate land clashed intensely with what lower-income households considered normatively appropriate. ${ }^{225}$ Even after 1700, when enclosures had become less controversial, issues such as gleaning rights remained highly contentious between higher and lower income households. ${ }^{226}$ Scholars therefore regularly portray the process of norm creation as one negotiated by highly self-interested parties, often with a shade of class-conflict. ${ }^{227}$

The striking thing about English property norms is not merely that they treated lower-income households less leniently than Chinese norms, but also that they became progressively less lenient over time: The normative position of small tenants, for example, deteriorated quite severely during the $16^{\text {th }}$ and $17^{\text {th }}$ Centuries as large landowners hacked away at traditional customs that protected copyholders and leaseholders. ${ }^{228}$

Mortgage laws and customs underwent a similar transformation. During the $12^{\text {th }}$ and $13^{\text {th }}$ Centuries, it was still possible to establish "living gages" (vivum vadium) - an archaic predecessor to mortgages - in which the debtor did not face any fixed deadline to redeem. ${ }^{229}$ Rather, the creditor would assume possession of the collateralized land, and whatever produce it generated would count towards the initial debt, along with any repayment the debtor might make. By the $15^{\text {th }}$ Century, this relatively debtor-friendly instrument had fallen into disuse, replaced almost completely by "mortgages" that required repayment within a fixed term. ${ }^{230}$ On the bright side, many local customs still guaranteed the defaulting debtor a foreclosure sale, so that he might at least recoup the full market value of the collateral. ${ }^{231}$ The deterioration of the debtor's institutional position accelerated, however, during the $16^{\text {th }}$ and $17^{\text {th }}$ Century: First, an increasing number of local customs cut down on repayment windows, to the point where mortgage

\footnotetext{
${ }^{224}$ See discussion at supra pp. _-_.

${ }^{225}$ BRENNER DEBATE, supra note 22, at 10-63; KERRIDGE, supra note 94; Hoyle, supra note 93; R.W. Hoyle, An Ancient and Laudable Custom: The Definition and Development of Tenant Right in NorthWestern England in the Sixteenth Century, 116 PAST \& PRESENT 24, 29-36 (1987) (portraying the evolution of tenant right as tensioned bargaining between lord and tenant).

${ }^{226}$ Peter King, Legal Change, Customary Right, and Social Conflict in Late Eighteenth-Century England: The Origins of the Great Gleaning Case of 1788, 10 LAW \& HIST. REV. 1 (1992).

${ }^{227}$ Such portrayals are also seen in, e.g., Rab Houston, Custom in Context: Medieval and Early Modern Scotland and England, 211 PAST \& PRESENT 35 (2011); Andy Wood, The Place of Custom in Plebeian Political Culture: England, 1550-1800, 22 SoC. HIST. 46 (1997).

${ }^{228}$ See discussion surrounding supra note 94.

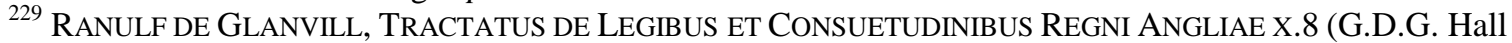
ed., 1965); .W. Chaplin, The Story of Mortgage Law, 4 HARV. L. REV. 1, 5-8 (1890).

${ }^{230}$ William BLACKSTONE, 2 COMMENTARIES ON THE LAWS OF ENGLAND 158 (Univ. of Chicago Press, 1979 edition).

${ }^{231}$ Zhang, supra note 7, at 184-85.
} 
contracts generally demanded redemption within a year of the original transaction. ${ }^{232}$ Second, the foreclosure sale was gradually replaced, both normatively and in practice, by automatic full conveyance to the creditor upon default, even if the initial mortgage sum fell far short of the land's full value. ${ }^{233}$ Clearly, property norms leaned increasingly towards wealthy, land-accumulating, households.

This brings us to point two. Even during the $16^{\text {th }}$ Century, when wealth disparity was not nearly as severe as in the $18^{\text {th }}$ Century, large English landowners enjoyed one distinct advantage over their Chinese peers: they possessed a near-monopoly on formal sociopolitical authority within local communities. Surveys of English localities during the $16^{\text {th }}$ and $17^{\text {th }}$ Centuries have repeatedly shown that recognition as a "gentleman" and the assumption of political responsibility were almost universally dependent upon the possession of substantial landed wealth. ${ }^{234}$ Scholars have traditionally argued, in fact, that higher levels of landownership directly "dictated" higher social and political status. $^{235}$ More recent studies have tempered this argument, demonstrating that other factors, including a consistent commitment to public service or long-term residency in the community, were comparably important. ${ }^{236}$ On the other hand, they continue to emphasize that significant landed wealth was at least a prerequisite for high status and, moreover, that other factors displayed considerable correlation with wealth: Because larger landowners generally had more settled residency patterns and stronger records of public service, the effects of these various factors were often conflated. ${ }^{237}$ In any case, a sociopolitical situation like that in Sibeichai, where most village leaders were actually below-average landholders, would have been unthinkable.

Why larger English landowners enjoyed this monopoly has no simple explanation. To some extent, it was buttressed by sociopolitical reorganization after the Black Death, in which the "the upper orders of English society drew together into a more cohesive government" to combat the social disorder created by the death of perhaps half the country's population. ${ }^{238}$ The large expansion in state power weakened, on the one hand, hereditary hierarchies between lords and subjects, but, on the other, because the state delegated local authority exclusively to the landed classes, it also excluded lower-income households more completely from positions of power. On the other hand, significant wealth-based stratification certainly predated the Black Death. ${ }^{239}$ Moreover, the monopolization of political authority by the landed classes was generally discussed in highly didactic terms - for example, the nobility and gentry were referred to by influential clergyman William Harrison as "those whome their race and blood or at least their vertues doo make noble and knowne"- that suggested at least some moral internalization. ${ }^{240}$ Most likely, moral internalization and state promotion went hand in hand. In any case, the status dominance of higher-income classes predated widespread

\footnotetext{
${ }^{232} I d$. at $182-83$.

${ }^{233}$ Sugarman \& Warrington, supra note 65.

${ }^{234}$ See sources at supra note 17.

${ }^{235}$ WRIGHTSON, supra note 17.

${ }^{236}$ French, supra note 17.

${ }^{237} \mathrm{Id}$.

${ }^{238}$ ROBERT C. PALMER, ENGLish LAW IN THE AGE OF THE BLACK DEATH 1348-1381, at 1 (2001).

${ }^{239} I d$. at $9-11$.

${ }^{240}$ WRIGHTSON, supra note 17 , at 27.
} 
landlord encroachment upon traditional customary property rights by over a century, and was almost certainly an important precondition.

There remains, for the sake of logical completeness, the issue of whether kinship networks influenced status distribution in England. In short: not significantly. While Alan Macfarlane's controversial work on "English individualism" is probably the first item that comes to mind on this, ${ }^{241}$ later scholarship confirms his basic findings with better evidence and more systematic analysis: that individual landowners were generally free to buy, sell or mortgage land without substantial interference from their kinship groups or traditional feudal hierarchies of landownership. ${ }^{242}$ Many, perhaps most, landowners preferred to keep their property within the family if possible, but "no one would deny that ... they had the right to buy and sell land without reference to their kin." 243 For most non-nobility, the "vital social bonds" in their lives were "not with an extended kinship group," 244 but rather with fellow community members. Theirs was a highly mobile society in which most personal relationships were cultivated upon mutual interest, rather than inherited, and, correspondingly, where wealth was the most, perhaps only, reliable indicator of sociopolitical status.

\section{Part Five: Conclusion}

The relative egalitarianism of Chinese property institutions is paradoxically explained by the prevalence and influence of kinship hierarchies in rural communities. This fundamentally revises the common perception that Chinese legal culture was one of caste-like inequality, socioeconomic stratification, and elite dominance. Quite the contrary, especially when compared to corresponding institutions in early modern England, Chinese kinship and property norms encouraged macro-level status equality between economic classes and, consequently, afforded stronger protection to lower income households. Although English law and custom had done away with most feudal indentures by the $17^{\text {th }}$ Century, law and custom continued to embrace wealth-based inequality in both status distribution and substantive property law. In comparison, by overriding wealth-based status inequality with "Confucian" kinship hierarchies, Chinese social norms actually promoted substantive socioeconomic equality.

Although this thesis focuses on social norms and customary law, the state has hardly been invisible. State support was clearly an important reason why kinship hierarchies were so embedded in Chinese society. ${ }^{245}$ Likewise, the consolidation of sociopolitical power in the English landed classes benefitted from state expansion after the Black Death. If legal authorities often took a back seat to social norms in direct regulation of land transaction, they were certainly center-stage in shaping the status distribution norms that underlay those norms. Quite ironically for Qing and Republican governments, property customs created under the influence of state-sponsored kinship norms often contradicted, indeed overrode, official property regulations. Many would

\footnotetext{
${ }^{241}$ MACFARLANE, supra note 12.

${ }^{242}$ Cressy, supra note 16; French \& Hoyle, supra note 16.

${ }^{243}$ French \& Hoyle, supra note 16, at 621.

${ }^{244}$ WRIGHTSON, supra note 17 , at 59.

${ }^{245}$ See discussion at supra pp. _-_.
} 
argue that the early modern English state behaved more consistently: both its status redistribution efforts and its forays into substantive property regulation-tenancy, mortgages, and so on-usually favored higher-income households. ${ }^{246}$ This contrast was not, however, due to any difference in the economic composition of officials: wealthy families dominated government ranks in both countries. More likely, it stemmed from differences in sociolegal culture, in what were internally understood to be the proper norms of status distribution.

The theoretical implications of this thesis are expansive. It urges, first of all, a reassessment of "Confucianism" and "Confucian" social hierarchies. Since at least the early $20^{\text {th }}$ Century, Chinese intellectuals have viciously attacked what they perceived as "feudal" ("fengjian") norms of "Confucian" hierarchy, which purportedly led to moral bankruptcy and the ruthless oppression of lower-income classes by a combination of large landowners, merchants, literati gentry, and perpetually corrupt government officials. ${ }^{247}$ Despite — or perhaps because of - the deep politicization of these ideas, they remain tremendously influential in the Chinese academic world even today, enjoying deep support among both self-identified Marxists and liberals. ${ }^{248}$ At the same time, they also continue to have surprising traction with Western intellectuals, many of whom have yet to advance substantively beyond the Weber and Wittfogel stereotypes of "Confucianism" as either fundamentally "irrational" or "despotic." 249

The conclusions presented here suggest that this stereotype is deeply flawed: Especially when compared to corresponding English norms, kinship hierarchies in both North China and the Lower Yangtze promoted, not suppressed, the cumulative sociopolitical status of lower-income households, facilitating the creation of property institutions that protected their economic interests against those of wealthier households. In fact, the closer real-life kinship organization resembled the Confucian ideal of strict ordering by generational seniority, the stronger its egalitarian socioeconomic effects: the comparison between Lower Yangtze and South China lineages is particularly illuminating. Interestingly, this does not necessarily exonerate kinship hierarchies from accusations of damaging economic growth. As I have argued elsewhere, the egalitarianism of "dian" and tenancy customs unfortunately deepened the relative underdevelopment of Chinese capitalism-whereas the harshness of English land customs towards smallholders and tenants was actually a long-term economic asset. ${ }^{250}$ $\mathrm{Be}$ as that may, if the primary economic problem with Confucian kinship hierarchies was that they were inefficiently benign towards the poor, then that already differs deeply from the conventional stereotype.

Along the way, this article has presented a substantially more ambitious - both theoretically and empirically - account of how property norms were shaped and reshaped in early modern China than is available in previous scholarship. It demonstrates how

\footnotetext{
${ }^{246}$ E.g., BRENNER DEBATE, supra note 22, at 10-63. But see Hoyle, supra note 93, at 5-6 (arguing that the pattern of state activity was not as distinctly class-based as Brenner suggests).

${ }^{247}$ Two of the most influential summaries of this intellectual mainstream are LI ZEHOU, ZHONGGUO XIANDAI SiXIANG SHI LUN [ON THE INTELLECTUAL History OF MODERN CHINA] (2008); WANG HUI, XIANDAI ZHONGGUO SiXIANG DE XINGQi [THE RISE OF MODERn CHINESE THOUGHT] (2008).

${ }^{248}$ Chen, supra note 1 (summarizing the general consensus); He, supra note 42 (laying out a typical "liberal" stance on this issue).

${ }_{249}$ See discussion surrounding supra notes 2-6, 40-44.

${ }^{250}$ Zhang, supra note 7.
} 
rationalistic self-interest and internalized kinship norms operated on different levels, and at different stages, of the norm-making process, indeed across different geographical regions and in an era of intense political turmoil and rapid economic change. More abstractly, it illustrates how internalized norms of status distribution influence, even predetermine, the rational and self-interested negotiation of property norms. The comparison with early modern England further diversifies the geographical and temporal applicability of this basic model.

The apparent ability to explain property institutions across highly diverse cultural and economic terrain hints, however tentatively, at the model's broader theoretical significance: While this article only demonstrates that sociological internalization and economic rationality can coexist and interact in social norm creation - in fact quite consistently with the hitherto empirically unproven "pyramid of norms" thesis ${ }^{251}$-a bigger question is how often they do so. Are most, perhaps even all, property norms the product of such interaction? Should we therefore explore "cultural paradigms" that explain divergent property norms in different societies, both historical and contemporary, even if we acknowledge that the immediate individual reaction to property institutions is one of economic self-interest? Ultimately, how much should we "culturalize" the law and economic analysis of property? ${ }^{252}$ At the very least, this article shows that, for those willing to work across academic disciplines and geographic boundaries, the analytical tools and empirical material to address these questions are readily available.

\footnotetext{
${ }^{251}$ See sources at supra note 27.

252 There is, of course, a growing "law and culture" literature that attempts to "culturalize" the economic analysis of law, if not directly within the realm of property law. See Robert Ahdieh, Beyond Individualism in Law and Economics, 91 Boston. UnIV. L. REV. 43 (2011); Rosa Ehrenreich Brooks, The New Imperialism: Violence, Norms, and the "Rule of Law," 101 MiCH. L. REV. 2275 (2003); Lan Cao, Culture Change, 47 VA. J. InT’L. L. 357 (2007); Amy J. Cohen, Thinking with Culture in Law and Development, 57 Buffalo L. REV. 511 (2009); Annelise Riles, A New Agenda for the Cultural Study of Law: Taking on the Technicalities, 53 BufFALO L. REV. 973 (2005).
} 